\title{
Why Does the Higashi-Izu Monogenetic Volcano Group Exist in the Izu Peninsula? : Relationships between Late Quaternary Volcanism and Tectonics in the Northern Tip of the Izu-Bonin Are
}

\author{
Masato Koyama* and Susumu Umino \\ Institute of Geosciences, Shizuoka University, Shizuoka 422, Japan
}

\begin{abstract}
A synthesis of available geological, petrological, and geophysical data was made to construct a model for explaining the relationships between the late Quaternary volcanism (the Higashi-Izu monogenetic volcano group, HIMVG) and tectonics in and around the Izu Peninsula, Japan. The Izu Peninsula and adjacent areas can be divided into three tectonic blocks: the western Izu (W-Izu), eastern Izu (E-Izu), and Oshima-Zenisu blocks. The vents or intrusions of the HIMVG are formed as open cracks aligning with the nearly NW-SE azimuth of horizontal maximum compression of regional stress in the E-Izu block. This stress field is mainly controlled by the NW-SE compression caused by the strong mechanical coupling of the buoyant Izu-Bonin are with the Japan arc. In spite of this compression, the upper crust of the E-Izu block is under weak lateral constraint on northeastward extension. Both the plate geometry involving an intra-plate fracture, the West Sagami Bay Fracture, and the existence of block rotations in the northern E-Izu block probably enable the northeastward upper crust extension in the E-Izu block, and make a monogenetic volcano field, where a new dike is formed in the upper crust at each eruptive or intrusive event.
\end{abstract}

\section{Introduction}

The 1989 off-Ito submarine eruption occurred off the east coast of the Izu Peninsula, Japan, which is located on the northern tip of the Izu-Bonin volcanic arc (Fig. 1), and generated a new submarine volcano, Teisi Knoll (e.g., Kato et al., 1990; Oshima et al., 1991). The Teisi Knoll Volcano is located on the northern edge of the spatial distribution of the Higashi-Izu monogenetic volcano group (HIMVG) (Fig. 2), which represents the latest volcanic products in the Izu Peninsula (Aramaki and Hamuro, 1977). The essential basaltic ejecta from the Teisi Knoll Volcano has a similar chemical composition to those of the HIMVG (Soya et al., 1989; Fujii et al., 1989). The location and chemical composition suggest that the eruption of the Teisi Knoll Volcano is the first historical activity of the HIMVG (Soya et al., 1989).

Received September 21, 1990; Accepted January 25, 1991

* To whom correspondence should be addressed. Present address: Faculty of Education, Shizuoka University, Shizuoka 422, Japan. 


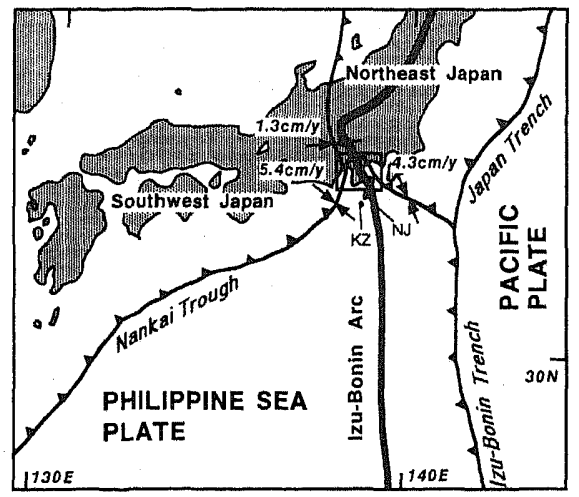

Fig. 1. Index map showing a plate tectonic setting around the study area. Rectangle: study area shown in Fig. 2. Thick solid line: convergence boundary between plates. Thick shaded line: location of the volcanic front in the Izu-Bonin and northeast Japan arcs. Arrows and associated numbers show the present convergence directions and rates between plates around the study area (Ishibashi, 1984). These directions and rates are based on the poles and angular velocities of plate motions by Minster and Jordan (1978, 1979). NJ, Niijima Island; KZ, Kozushima Island.

The HIMVG is classified into one of the independent groups of monogenetic volcanoes (IGMV) in Japan (Nakamura, 1986, 1989). An IGMV is composed only of small monogenetic volcanoes, which have no evident central vent or volcano, and in many cases represents a tectonic situation with weak constraint on lateral crustal extension (Nakamura, 1986). In fact, many of the IGMVs in the world are distributed on a continental craton, or a backarc region, rarely near the volcanic front (Nakamura, 1986). However, the HIMVG is distributed in the eastern Izu Peninsula, which is located just inside the Izu-Bonin arc volcanic front (Fig. 1).

There is no evidence of tensional tectonics in the Izu Peninsula in the present and late Quaternary time, except for the HIMVG activity. The Izu block, which includes the Izu Peninsula and adjacent submarine parts, collided with the Japan arc at about 1 Ma (Amano et al., 1986; Kitazato, 1986; Koyama, 1986) and is subducting buoyantly beneath it (Ishibashi, 1986). Active faults distributed in the Izu Peninsula are dominantly strike-slip ones, except for the several normal faults in the western part (Hoshino et al., 1978). The majority of the earthquakes which occurred in and around the eastern Izu Peninsula have source mechanisms of strike-slip type (e.g., Hori, 1989; Ukawa, 1991). Several large composite volcanoes had been active during the early and middle Pleistocene in the Izu Peninsula before the initiation of the HIMVG activity (Koyama, 1986, 1988, Fig. 3). Such activities of large composite volcanoes are believed to contrast with an IGMV activity, and to be consistent with a more compressional tectonic situation (Nakamura, 1986, 1989). Thus, the existence of an IGMV in the Izu Peninsula is rather a paradoxical fact.

In this paper, we first summarize the stratigraphy and petrology of the HIMVG, 


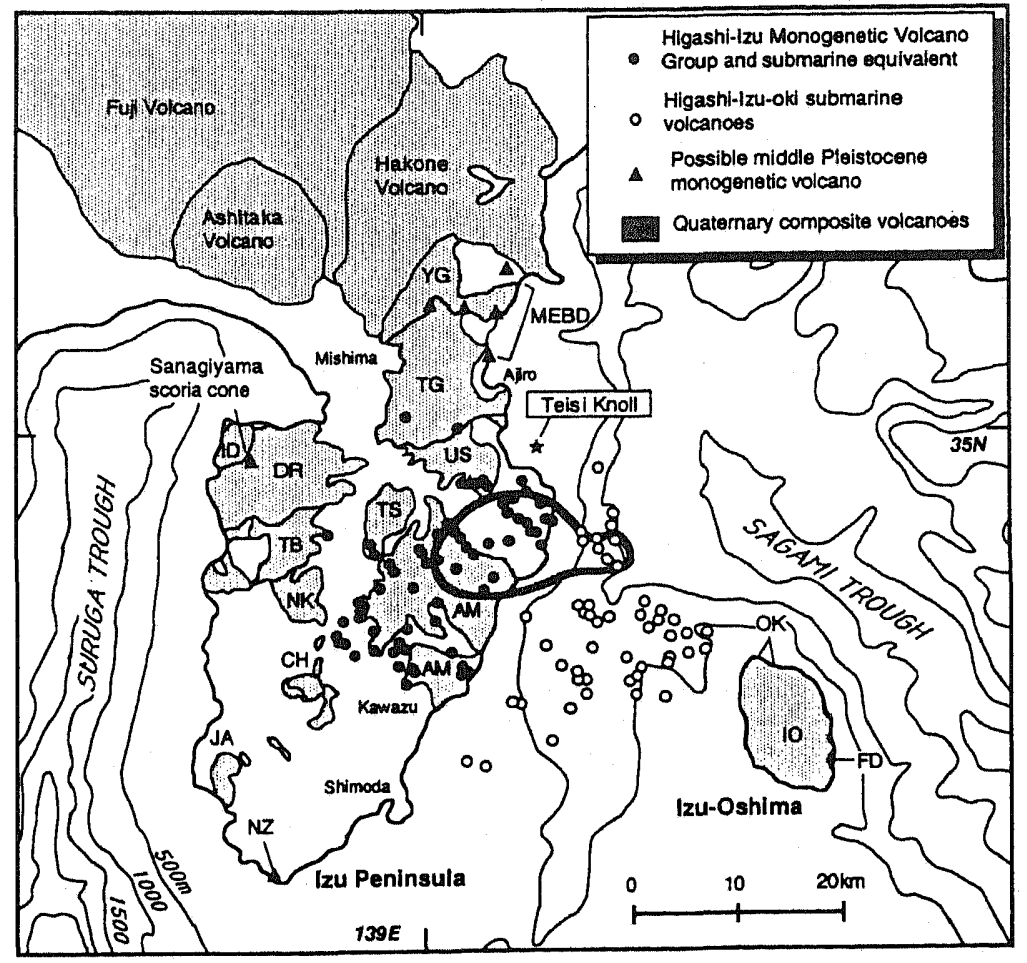

Fig. 2. Locality and spatial distribution of the Higashi-Izu monogenetic volcano group, the Higashi-Izu-oki submarine volcanoes (Hamuro et al., 1980, 1983), and other Quaternary volcanoes in and around the Izu Peninsula. Abbreviations are: YG, Yugawara Volcano; MEBD, minor effusive bodies of pyroxene dacite (Kuno, 1952); TG, Taga Volcano; US, Usami Volcano; TS, Tenshi Volcano; AM, Amagi Volcano; ID, Ida Volcano; DR, Daruma Volcano; TB, Tanaba Volcano; NK, Nekko Volcano; CH, Chokuro Volcano; JA, Jaishi Volcano; NZ, Nanzaki Volcano; OK, Okata Volcano; FD, Fudeshima Volcano; IO, Izu-Oshima Volcano. Thick shaded line shows the distribution limit of andesite volcanoes of the Higashi-Izu monogenetic volcano group and the HigashiIzu-oki submarine volcanoes (Hamuro, 1985). The depth contour interval is $500 \mathrm{~m}$.

and clarify the eruptive history and petrological characteristics of their activities. Secondly, we summarize and discuss geological and geophysical data on the plate geometry and crustal structure in and around the Izu Peninsula, and clarify the tectonic situation in the HIMVG region. Thirdly, synthesizing all the data and inferences, we propose a model for the HIMVG eruption, and try to explain why an IGMV exists in the Izu Peninsula. 


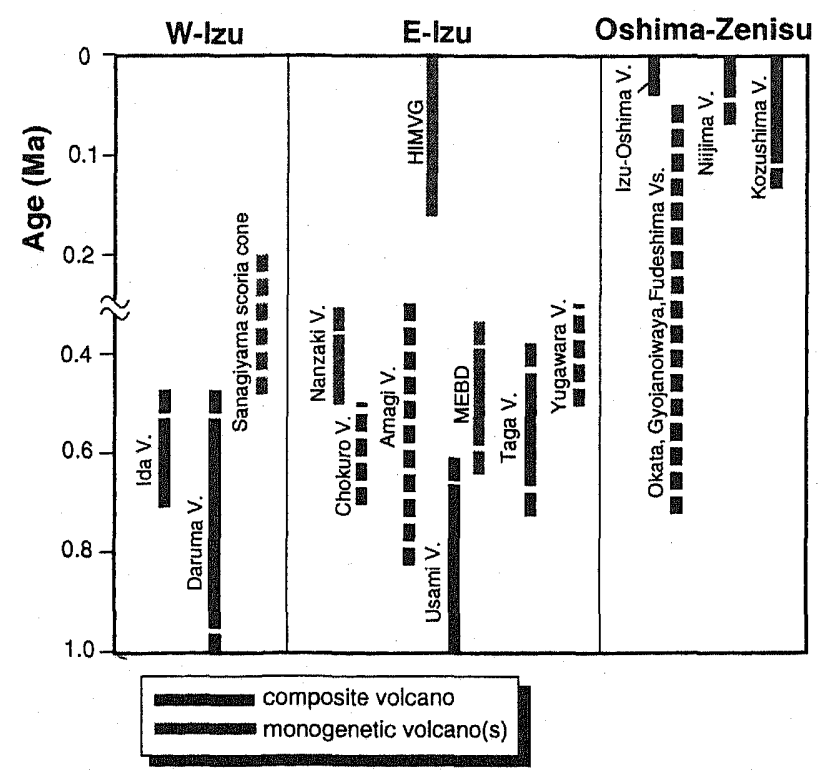

Fig. 3. Summary of the volcanic history in the Izu Peninsula and adjacent areas for the last $1 \mathrm{~m} . \mathrm{y}$. Ages of the volcanoes other than the Higashi-Izu monogenetic volcano group are based on Kaneoka et al. (1988), Kikawa et al. (1989), Shirao (1981), Suzuki (1970), and Isshiki (1982, 1984, 1987). W-Izu, E-Izu, and Oshima-Zenisu are the names of tectonic blocks (see text and Fig. 10).

\section{Geology, Petrology, and Eruptive History}

\subsection{Geologic setting}

Almost all the formations exposed in the Izu Peninsula are submarine and terrestrial volcanics erupted since the early Miocene, and their reworked deposits. Accompanying the collision with the Japan arc at about $1 \mathrm{Ma}$, the whole area of the Izu Peninsula was uplifted, and terrestrial volcanic products, the Atami Group, has deposited during the Quaternary time. The products of the HIMVG constitute the uppermost part of the Atami Group (Koyama, 1986, 1988).

The HIMVG is composed of over 70 terrestrial small monogenetic volcanoes, which are distributed over the area of $350 \mathrm{~km}^{2}$ in the eastern part of the Izu Peninsula (Figs. 2 and 4). Besides these, the western half of the Higashi-Izu-oki submarine volcanoes, distributed off the east coast of the Izu Peninsula, can be regarded as a submarine equivalent of the HIMVG because of their similar petrology (Hamuro et al., 1980, 1983).

The HIMVG is composed of scoria cones, maars, and lava flows and domes, many of which accompany scoriaceous pyroclastic fall deposits. Only the Kawagodaira Volcano (No. 54 in Fig. 4) has pyroclastic flows and plinian pumice fall deposits. The magma discharge volume of each volcano is mostly less than $0.1 \mathrm{~km}^{3}$, except for the Omuroyama (No. 25), Komuroyama (No. 11), Kawagodaira (No. 54), and Chikubo (Nos. 20 and 21) Volcanoes, each of which has a discharge volume of $>0.2 \mathrm{~km}^{3}$ (Fig. 5). 


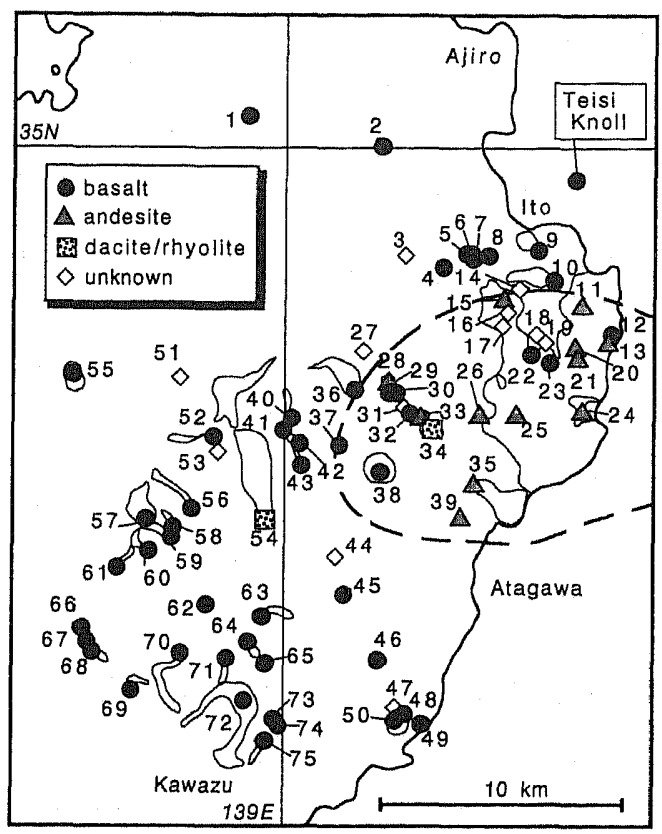

Fig. 4. Location and rock type of each vent of the Higashi-Izu monogenetic volcano group. 1, Takatsukayama; 2, Sukumoyama; 3, Kashiwatoge-nishi*; 4, Babanotaira (Hachigakubo-5); 5-8, Hachigakubo-1-4; 9, Uchino; 10, Joboshi; 11, Komuroyama; 12, Kawana-minami; 13, Sannohara-kita; 14, Akasaka-minami; 15, Kadono; 16, Ikeda-higashi; 17, Ogi; 18, Ippekiko; 19, Higashi-Oike; 20, Chikubo-central cone; 21, Chikubo-somma; 22, Arayama; 23, Takamuroyama; 24, Harai; 25, Omuroyama; 26, Dainoyama; 27, Ohatano; 28, Iwanoyama; 29, Iwanokubo-nishi; 30, Iwanokubo-higashi; 31, Fujimikubo; 32. Ananokubo; 33, Ananoyama; 34, Yahazuyama; 35, Iyuzan; 36, Marunoyama; 37, Sugehiki; 38, Togasayama; 39, Akakubo; 43-40, Jizodo-1-4; 44, Shiranutanoike; 45, Kawakubogawa (Amagi Highland-higashi); 46, Sekiguchi*; 50-47, Inatori-1-4; 51, Kitanohara-higashi; 52, Nagano-higashi*; 53. Hokihara-higashi; 54, Kawagodaira; 55, Funabara; 56, Yoichizaka; 57, Hachikuboyama; 58, Iwabigawa*; 59, Maruyama*; 60, Esashinomine*; 61, Namezawa* (Hontanigawa-shiryu); 62, Haccho-rindo; 63, Sekiguchigawajoryu; 64, Kannonyama-higashi; 65, Misujiyama-nishi (Hachiyama-higashioku); 66, Numanokawa-3; 67, Numanokawa-4*; 68, Numanokawa-2; 69, Numanokawa-1*; 70, Noborio-minami; 71, Odaira; 72, Hachinoyama (Hachiyama); 73, Koike; 74, Oike; 75, Kamisagano-higashi (Oike-minami). Asterisk shows the vent found or redefined by this study. Names in parentheses are the names used by Aramaki and Hamuro (1977). Rock types are after Hamuro (1985) and Umino et al. (1991). Ellipse of broken line shows the distribution limit of andesite volcanoes of the Higashi-Izu monogenetic volcano group and the Higashi-Izu-oki submarine volcanoes (Hamuro, 1985). Thin line shows the distribution of lava and pyroclastic flows from the vents. 


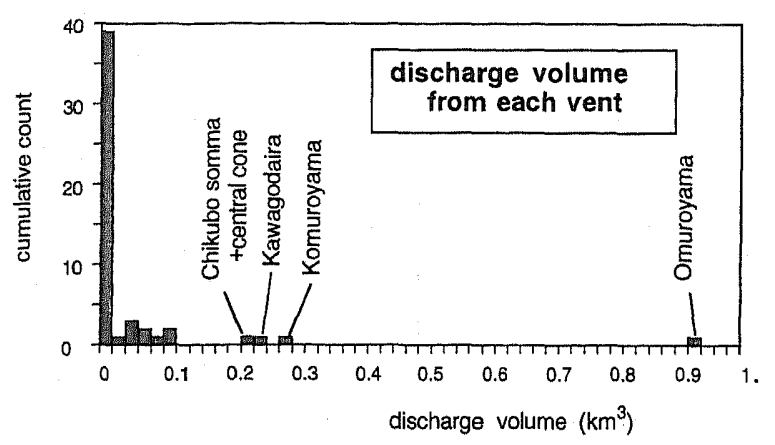

Fig. 5. Histogram of magma discharge volume from each vent of the Higashi-Izu monogenetic volcano group. The discharge volume data are after Aramaki and Hamuro (1977).

\subsection{Eruptive history and spatial vent distribution}

Stratigraphy of the HIMVG has been examined by several previous studies (e.g., Kuno, 1954; Aramaki and Hamuro, 1977; Hamuro, 1978, 1985; Mizuno et al., 1990; Koyama and Hayakawa, 1990). Aramaki and Hamuro (1977) and Hamuro (1978) first recognized the HIMVG as an independent volcano group and constructed the basic framework of their stratigraphic relationships. Mizuno et al. (1990) recognized several widespread tephras from the outside of the Izu Peninsula, and estimated the initiation of the HIMVG to be $>100 \mathrm{ka}$. Koyama and Hayakawa (1990) recognized several new vents of the HIMVG, and constructed the detailed eruptive history of the HIMVG based on tephrochronology and loesschronometry, additionally using paleomagnetic correlations and all the available ${ }^{14} \mathrm{C}$ ages. The loesschronometric method is based on the constant accumulation rate $(7 \mathrm{~cm} / \mathrm{k} . \mathrm{y}$. in average) of eolian loam deposits in Japan (Hayakawa and Yui, 1989; Hayakawa, 1990). The paleomagnetic correlation is based on the comparison of the remanent magnetization directions of lava flows with the standard paleomagnetic secular variation curve.

Preliminary stratigraphy and chronology of the HIMVG are summarized in Fig. 6. Of all the 75 volcanoes of the HIMVG, the ages of 59 volcanoes were estimated. Stratigraphic horizons of each volcano and each widespread tephra from the outside of the study area, are schematically shown in this figure. This diagram is based on the results by the previous stratigraphic studies (Aramaki and Hamuro, 1977; Hamuro, 1978, 1985; Kato, 1990; Mizuno et al., 1990; Koyama and Hayakawa, 1990), and on the tephrochronologic correlations of the widespread tephras with those distributed in other regions (Shirao, 1981; Sugihara, 1981; Mizuno et al., 1990; Koyama and Hayakawa, 1990). Further detailed descriptions of the stratigraphy, chronology, correlation, and mode of emplacement of each tephra will be shown in a future paper (Koyama and Hayakawa, in preparation).

The initiation of the HIMVG activity has once been estimated to be $30-40 \mathrm{ka}$ by Aramaki and Hamuro (1977). Mizuno et al. (1990) recognized that the products from the Takatsukayama Volcano (No. 1 in Fig. 4) underlie a plinian pumice fall deposit OP (Fig. 6), and correlated the OP with the Ky ash (110-120 ka) in the Omaezaki area 


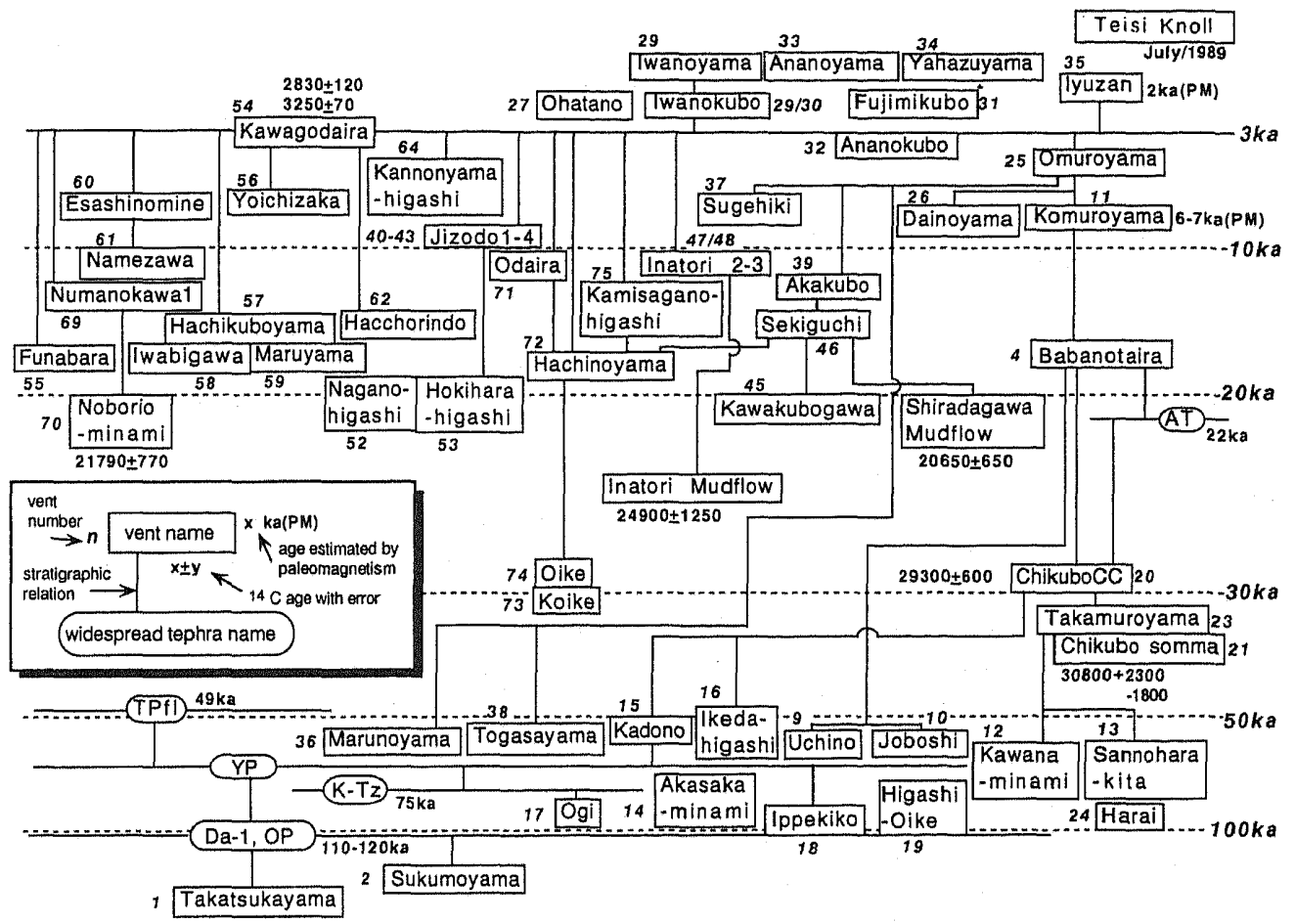

Fig. 6. Preliminary summary of the stratigraphy and chronology of the Higashi-Izu monogenetic volcano group (HIMVG) and associated widespread tephras. Box shows the horizon of each vent of the HIMVG and intercalated two mudflow deposits (Inatori and Shiradagawa mudflows). The vent numbers are the same as in Fig. 4. Ellipse shows the horizon of widespread tephras from the outside of the study area. Stratigraphic relationship observed in an outcrop is shown with a solid line. Chronologic data are based on loesschronometry, ${ }^{14} \mathrm{C}$ ages, and paleomagnetic correlation (see text). Horizons of 15 vents (Kashiwatoge-nishi, Hachigakubo-1-4, Arayama, Shiranutanoike, Inatori-1 and 4, Kitanohara-higashi, Sekiguchigawa-joryu, Misujiyama-nishi, Numanokawa-2-4) are unknown and are not shown in this figure.

to the west of the Izu Peninsula. From this result, Mizuno et al. (1990) estimated the initiation of the HIMVG to be $>100 \mathrm{ka}$. Koyama and Hayakawa (1990) also found that scoria fall deposits from the Takatsukayama and Sukumoyama (No. 2) Volcanoes underlie the OP (Fig. 6). The total thicknesses of loess between the OP and the Takatsukayama and Sukumoyama deposits are 200 and $40 \mathrm{~cm}$, respectively. On the basis of the accumulation rate of loess stated above $(7 \mathrm{~cm} / \mathrm{k} . \mathrm{y}$.$) , the ages of the$ Takatsukayama and Sukumoyama Volcanoes are estimated to be 140-150 and $115-125 \mathrm{ka}$, respectively. Although the ages of 15 volcanoes are still unknown, the Takatsukayama and Sukumoyama Volcanoes are the stratigraphically lowest volcanoes in Fig. 6. Thus, we estimate the initiation of the HIMVG activity to be at least

Vol. 39, No. 1, $1991^{\circ}$ 


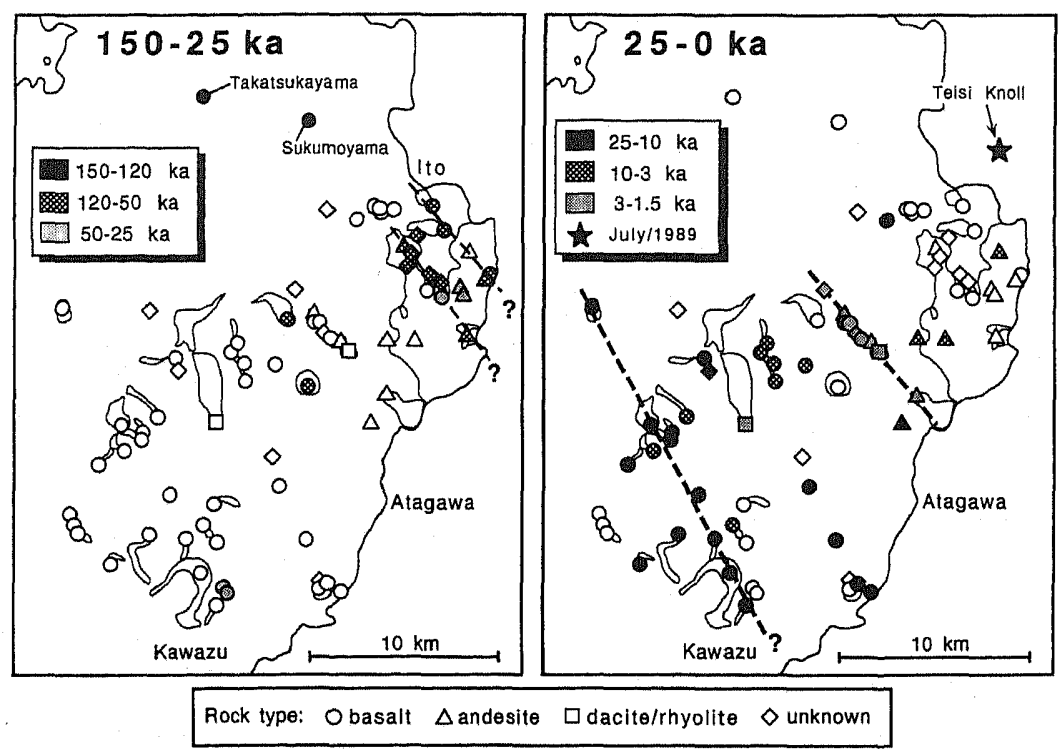

Fig. 7. Spatial and temporal distribution of active vents of the Higashi-Izu monogenetic volcano group: (left) $150-25 \mathrm{ka}$, (right) $25-0 \mathrm{ka}$. Thick broken lines show possible vent alignments in each period. Other symbols are the same as in Fig. 4.

$140-150 \mathrm{ka}$.

Figure 7 shows the spatial and temporal distribution of activities of the 60 HIMVG volcanoes in Fig. 6. This figure suggests that the activity of the HIMVG initiated around the northern edge of the present distribution, and then extended southward. The whole area of the present distribution seems to have been active since $25 \mathrm{ka}$.

Hamuro (1978) recognized four alignments of the HIMVG vents and named them Lines $1,1^{\prime}, 2$, and 3, respectively (Fig. 8). Of these, Lines $1,1^{\prime}$, and 3 have NW-SE trends. Similar NW-SE alignments of volcanoes also exist in the Higashi-Izu-oki submarine volcanoes (Aramaki and Hamuro, 1977) (Fig. 2). Figure 7 shows that several volcanoes lying on a single NW-SE alignment were active during a limited time interval. This is well shown in Line 3, where nine vents were active in the same period (1.5-3 ka).

Similar vent alignments seem to exist on Lines 1 and $1^{\prime}(50-120 \mathrm{ka})$, and Line 4 (10-25 ka). According to the paleomagnetic results by Heki (1983), lava flows from the Hachikuboyama (No. 57 in Fig. 4), Haccho-rindo (No. 62), and Hachinoyama (No. 72) Volcanoes, which align along Line 4 with an NNW-SSE trend (Fig. 7), have very similar (with $<5^{\circ}$ differences) paleomagnetic directions. The scoria fall deposits from the Hachikuboyama Volcano overlie the lava flows from the Maruyama (No. 59) and Iwabigawa (No. 58) Volcanoes without a visible layer of loess between them, and their vent locations nearly align with Line 4 (Fig. 7). Thus, these five volcanoes lying on Line 4 seem to have been active in the same period.

Besides these alignments, there is a tendency for two or three adjacent volcanoes 


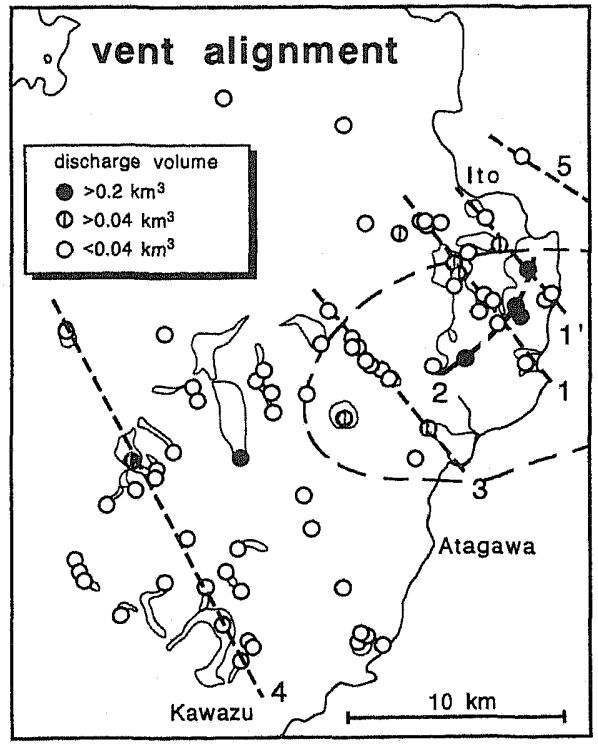

Fig. 8. Summary of the spatial distribution of possible vent alignments of the Higashi-Izu monogenetic volcano group (see text). Spatial distribution of vents with large magma discharge volume (after Aramaki and Hamuro, 1977) is also shown. Other symbols are the same as in Fig. 4.

with a similar mode of eruption to form a short alignment with an NW-SE trend. This suggests the possibility that these volcano groups on the same lines were concurrently active with the same mode of eruption under a similar geological situation. Such lineation can be seen among the Ippekiko (No. 18 in Fig. 4) and Higashi-Oike (No. 19) Volcanoes (both are maars) on Line 1, the Iwanoyama (No. 28), Ananoyama (No. 33), and Yahazuyama (No. 34) Volcanoes (all are lava domes) on Line 3, the Iwanokubo (Nos. 29 and 30) and Fujimikubo (No. 31) Volcanoes (both are small maars) also on Line 3, the Nagano-higashi (No. 52) and Hokihara-higashi (No. 53) Volcanoes (both are maars).

The location of the Teisi Knoll Volcano and the epicenters of the earthquakes associated with the 1989 eruption are distributed along a line with an NW-SE trend (Line 5 in Fig. 8). Although this line does not correspond to any vent alignment of the HIMVG, many studies suggest the magma intrusion along this line associated with the recent crustal activity (e.g., Tada and Hashimoto, 1989, 1991; Shimazaki, 1989; Okada and Yamamoto, 1989, 1991). Thus, we regard Line 5 as an equivalent of the vent alignments of the HIMVG.

The NW-SE trends of vent alignments during the same period (Fig. 8) are well concordant with the trends of maximum horizontal compressional axes $\left(\sigma_{H_{\max }}\right)$ of regional crustal stress in the eastern Izu Peninsula (Fig. 10). In contrast with these NW-SE alignments, Line 2 does not seem to accompany any coeval eruptions (Figs. 7 and 8 ). Line 2 can only be recognized as an alignment of the volcanoes with the largest discharge volume $\left(>0.2 \mathrm{~km}^{3}\right)$ (Fig. 8), and its significance is unclear.

Vol. 39, No. 1, 1991 


\subsection{Petrologic characteristics and magma discharge rate}

The petrography and petrology of the HIMVG and a part of the Higashi-Izu-oki submarine volcanoes have already been examined in several papers (e.g., Kuno, 1954; Aramaki and Hamuro, 1977; Hamuro et al., 1980, 1983; Hamuro, 1985; Miyajima et al., 1985; Miyajima, 1990; Umino et al., 1991). According to these works, the volcanic rocks of the HIMVG are composed of basalt-basaltic andesite $\left(\mathrm{SiO}_{2}=49-60 \mathrm{wt} \%\right)$ and dacite-rhyolite $\left(\mathrm{SiO}_{2}=68-74 \mathrm{wt} \%\right)$, showing a bimodal distribution of $\mathrm{SiO}_{2}$ compositon. Andesitic rocks often include tonalitic xenoliths or xenocrysts (Hamuro, 1985; Miyajima et al., 1985; Miyajima, 1990; Umino et al., 1991), and sometimes yield basaltic inclusions or olivine xenocrysts (Umino et al., 1991). Petrologic characteristics of these rocks show that the dacitic-rhyolitic magma of the HIMVG originated from the melting of the tonalitic upper crust (Hamuro, 1985), and that the andesitic magma was formed by fractional crystallization or by assimilation with the tonalitic upper crust (Miyajima et al., 1985; Miyajima, 1990; Umino et al., 1991).

Figure 9 shows the temporal variation of magma discharge rate and volume of the HIMVG. The total magma discharge rate of the HIMVG seems to have rapidly increased since $10 \mathrm{ka}$ (Fig. 9(A)). Three of the four largest eruptions $\left(>0.2 \mathrm{~km}^{3}\right)$ occurred in the latest stage (0-10 ka) (Fig. 5). Andesitic and dacitic- rhyolitic activities are particulary
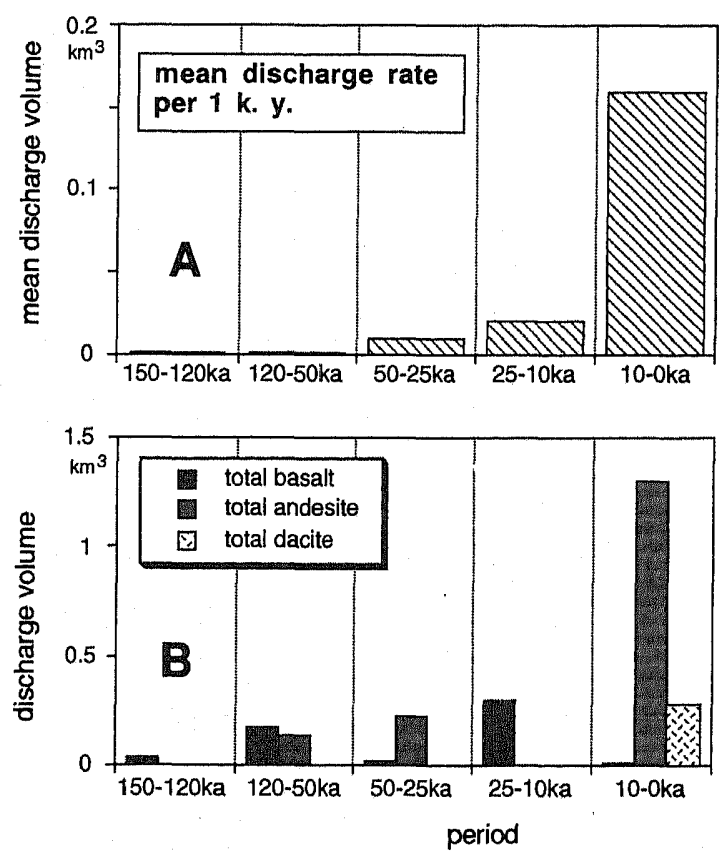

Fig. 9. Temporal variations of magma discharge rate volume of the Higashi-Izu monogenetic volcano group (HIMVG). Discharge volume data are after Aramaki and Hamuro (1977). (A) Temporal variation of the mean discharge rate of the whole HIMVG per 1 k.y. (B) Temporal variation of total discharge volume for each rock type. 
dominant for the last $10 \mathrm{ka}$ (Fig. 9(B)). No dacitic-rhyolitic activity existed before the eruption of the Kawagodaira Volcano (No. 54 in Fig. 4) at $3 \mathrm{ka}$.

Andesitic and dacitic-rhyolitic volcanoes of the HIMVG are limited to the northern central part of the whole distribution of the HIMVG and the submarine equivalent (Figs. 2 and 4), while many of the basaltic volcanoes exist in the outer zone (Fig. 4), forming a concentric zonal distribution of $\mathrm{SiO}_{2}$ composition (Hamuro, 1985; Miyajima et al., 1985; Miyajima, 1990). Similar concentric zonal patterns exist in modal abundance of xenocrysts, in assemblages of phenocrysts and groundmass minerals (Hamuro, 1985; Miyajima et al., 1985; Miyajima, 1990), and in chemical compositions of olivine and spinel (Umino et al., 1991). All these concentric zonal distributions can be explained by melting of the tonalitic upper crust and its assimilation with a parent magma below the central part of the concentric zoning (e.g., Umino et al., 1991). Spatial distribution of magma discharge volume shows that many of the volcanoes with large discharge volume $\left(>0.04 \mathrm{~km}^{3}\right)$ are located in the central part of the concentric zonation (Fig. 8).

\section{Tectonic Setting}

Figure 1 shows the present plate arrangement and their relative motions around the study area. The convergence between the northeast and southwest Japan arcs is based on the hypothesis of the nascent subduction along the eastern edge of the Japan Sea (Nakamura, 1983; Kobayashi, 1983) since 0.5 Ma (Seno, 1985). Because of this relative convergence, in the study area, the Philippine Sea (PHS) plate moves northnorthwestward against the northeast Japan arc, and northwestward against the southwest Japan arc, respectively.

Several models have been proposed to systematically explain the present and late Quaternary tectonics in and around the Izu Peninsula on the basis of geophysical, geomorphological, and geological data. Almost all these models have a common sense that the Izu Peninsula is located on the northernmost tip of the Philippine Sea plate, and is colliding with or buoyantly subducting beneath the northeast Japan arc. However, these models have many disagreements of views on details with each other.

These models can be classified into two groups; one regards the whole Izu Peninsula as a single tectonic domain (e.g., Nakamura et al., 1984; Ukawa, 1991), and the other regards it as composed of two domains with different tectonic features (e.g., Somerville, 1978; Nakano et al., 1980; Kobayashi, 1980; Tsukahara and Ikeda, 1983, 1987; Hoshino, 1984; Kasahara, 1984; Ida, 1991). However, even within the same group, each model has a different interpretation. For example, Nakamura et al. (1984) regard the bending of the PHS plate associated with the subduction along the Sagami and Suruga troughs as the most important factor dominating the regional stress field and tectonics in and around the Izu Peninsula, while Ukawa (1991) emphasizes the role of the collision of the Izu block with Honshu.

In this paper, we propose a new model for the present and late Quaternary tectonics in and around the Izu Peninsula, and discuss its validity. Our model considers the study area to be composed of at least three tectonic domains, and emphasizes the role of the slab geometry involving the West Sagami Bay Fracture (WSBF) proposed by Ishibashi

Vol. 39, No. 1, 1991 


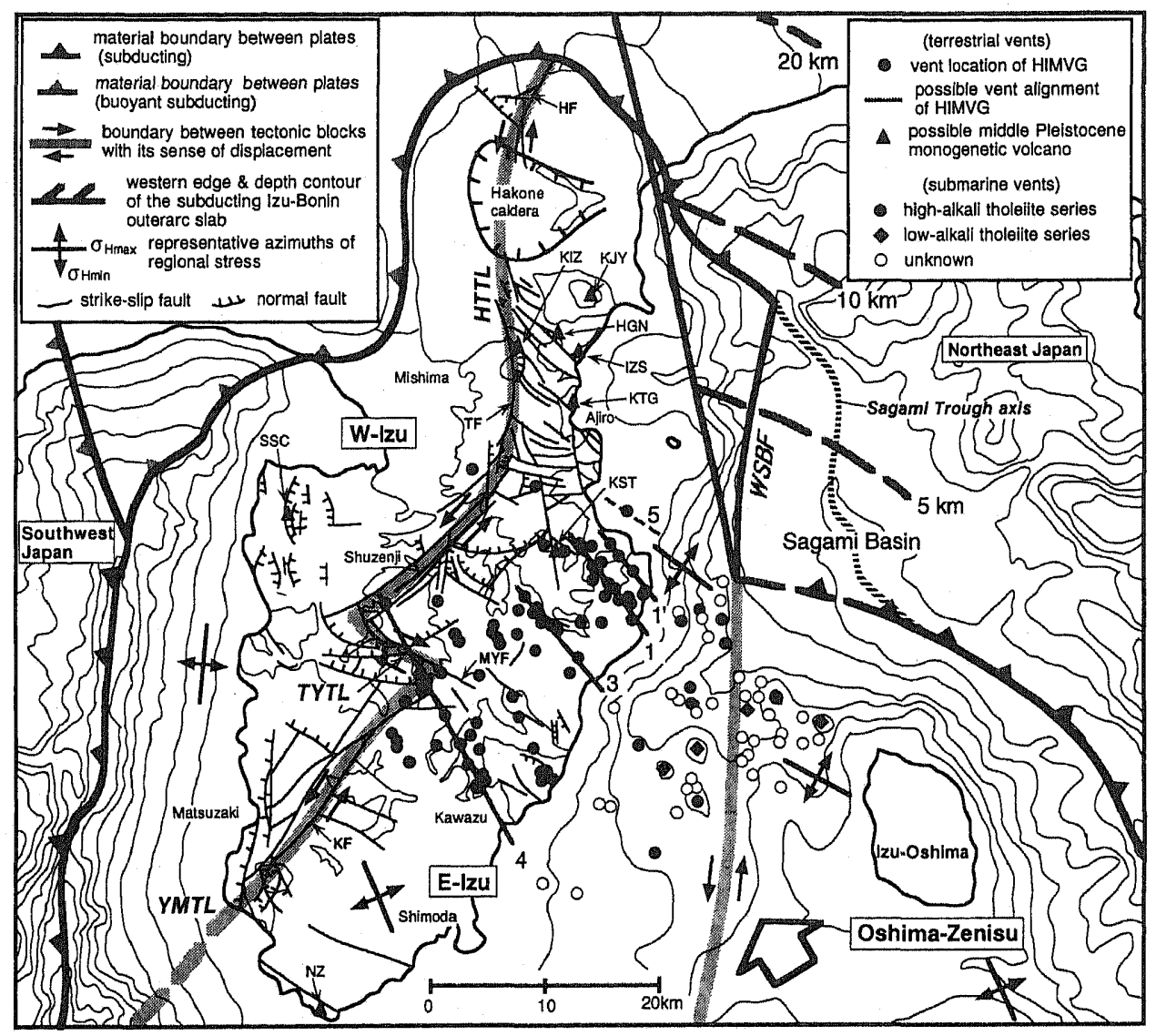

Fig. 10

(1988). In this section, we first examine the reality of the WSBF hypothesis by Ishibashi (1988). Secondly, we propose a division of tectonic domains, and discuss their tectonic significance. Thirdly, we summarize paleomagnetic data from the study area, and clarify systematic block rotations in the eastern Izu Peninsula.

\subsection{West Sagami Bay Fracture and its reality}

It has been commonly accepted that in Sagami Bay, the PHS slab downdips northeastward from the axis of the Sagami trough without any intra-plate fracturing (e.g., Nakamura et al., 1984). In contrast with this, Ishibashi (1988) proposed a new geometry of the PHS slab involving an intra-plate fracture, the West Sagami Bay Fracture (WSBF) (Fig. 10). This hypothesis is based on geodetic data before and after the 1923 Kanto earthquake, seismotectonic model calculation, submarine geomorphology, and the tectonic history of the whole Izu-Bonin arc-Japan arc collision zone since the middle Miocene. The WSBF was hypothesized to be caused by the difference in buoyancy of slabs; the Izu-Bonin outerarc can subduct beneath the northeast Japan 
arc, while the more buoyant Izu-Bonin innerarc cannot subduct but underplate the northeast Japan arc. The Izu-Bonin outerarc separates from the Izu-Bonin innerarc at the southern end of the WSBF, and subducts north-northwestward. Figure 10 shows the location of the WSBF and the depth contour of the subducting Izu-Bonin outerarc. after Ishibashi (1988).

The WSBF hypothesis involves the downdipping of the Izu-Bonin outerarc slab not from the Sagami trough axis but from the southern edge of the Sagami basin (Fig. 10). This geometry requires a local change of downdip direction of the slab from east-northeastward on the eastern side of the Izu-Oshima Island to north-northeastward on the northern side of the island. Submarine topography (Fig. 10) and gravity anomaly (Kono and Furuse, 1989) show an evident escarpment with an N-S trend along the WSBF, and also show a change of slope strike from NNW-SSE on the eastern side of the Izu-Oshima Island to WNW-ESE on the northern side of the island, probably reflecting the change of downdip direction of the subducting slab. Nakamura et al. (1984) proposed that near a subduction zone, a stress field in an underthrusting plate is controlled by bending of the plate preceding its subduction, and that the axes of minimum horizontal compressional stress $\left(\sigma_{H_{\min }}\right)$ resulted from the bending align with the downdip direction of the slab. If this principle and the WSBF hypothesis are true, the azimuth of $\sigma_{H_{\min }}$ should change from ENE-WSW on the southeastern side of the Izu-Oshima Island to NNE-SSW on the northwestern side of the island (Fig. 10).

Fig. 10. Map showing the tectonic features in and around the Izu Peninsula, and the spatial distribution of vents of the Higashi-Izu monogenetic volcano group (HIMVG) and other possible monogenetic volcanoes. The locations and rock types of the Higashi-Izu-oki submarine volcanoes are after Hamuro et al. (1980, 1983). The location of the material boundary between plates is after Nakamura et al. (1984), except for that in the Sagami Bay area. Large arrow shows the relative convergence direction of the Philippine Sea plate against northeast Japan after Ishibashi (1984). Contour interval of submarine topography is 250 $\mathrm{m}$. Thick broken contour shows the depth contour of the surface of subducted Izu-Bonin outerarc slab (after Ishibashi, 1988). Shaded lines with numbers are the possible NW-SE vent alignments of the HIMVG (Fig. 8). Thick solid line with arrows shows the representative azimuths of horizontal maximum and minimum compressional stress $\left(\sigma_{H_{\min }}\right.$ and $\sigma_{H_{\max }}$, respectively), which were traced from the regional stress data by Tsukahara and Ikeda $(1983,1987)$, Hori (1989), and Ukawa (1991). Abbreviations are: WSBF, West Sagami Bay Fracture (after Ishibashi, 1988); W-Izu and E-Izu, western and eastern Izu blocks; Oshima-Zenisu, Oshima-Zenisu block; HTTL, Hirayama-Tanaba tectonic line; TYTL, Tanaba-Yugashima tectonic line; YMTL, YugashimaMatsuzaki tectonic line; HF, TF, MYF, and KF, Hirayama, Tanna, Mizunuki-Yoichizaka, and Kadono faults; KJY, Kajiya Dacite; HGN, Higane Dacite; IZS, Izusan Dacite; KIZ, Karuizawa Dacite; KTG, Kamitaga Dacite; KST, Kashiwatoge Dacite; SSC, Sanagiyama scoria cone; NZ, Nanzaki Volcano. On land geological data are based on Koyama $(1982,1986,1988)$ and Koyama (unpublished data), Hoshino et al. (1978), Kuno (1952), and Shirao (1981). 

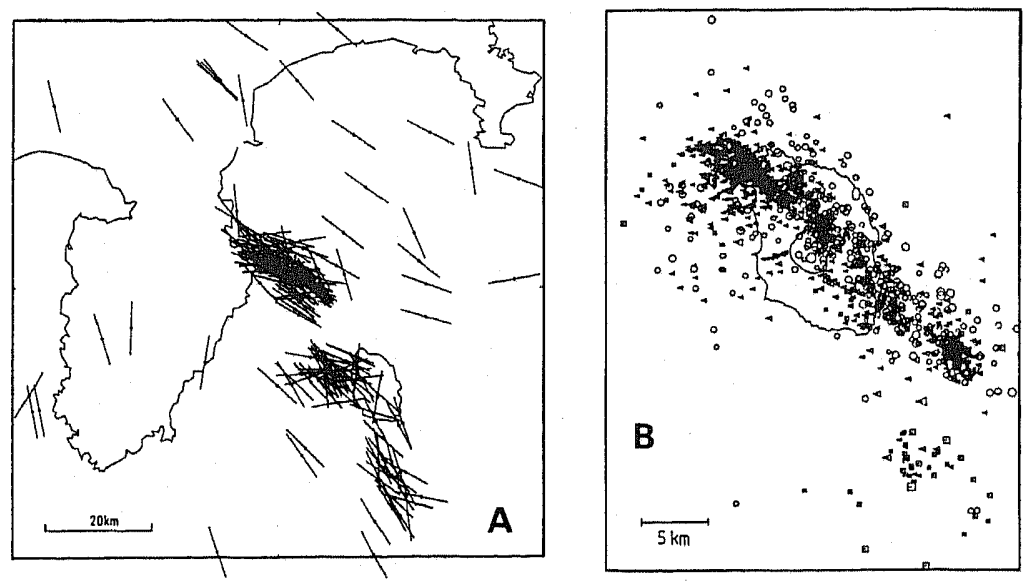
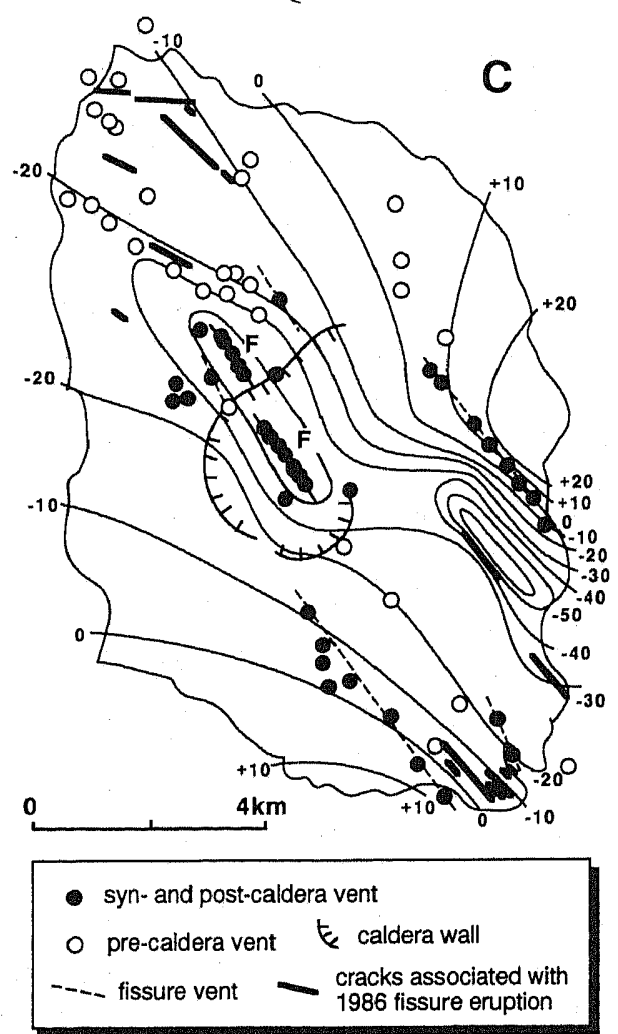

Fig. 11. Evidence for the directional changes of regional stress around the Izu-Oshima Island. (A) Distribution of $P$-axes of shallow earthquakes (mostly $<25 \mathrm{~km}$ ) in and around the Izu Peninsula (Hori, 1989). (B) Epicentral distribution in and around the Izu-Oshima Island during and after the 1986 fissure eruption of Izu-Oshima Volcano (Yamaoka et al., 1988). Symbols show the focal depths (circle, $<5 \mathrm{~km}$; triangle, $>5 \mathrm{~km}$ and $<10 \mathrm{~km}$; square, $>10 \mathrm{~km}$ ). The size of the symbols represents the difference in the earthquake magnitudes. (C) Map showing the distribution of fissure vents ( $F$ in figure) and cracks (thick lines), and geodetic vertical displacement in the Izu-Oshima Island during the 1986 fissure eruption of IzuOshima Volcano (after Endo et al., 1988). Contour shows the height change (in $\mathrm{cm}$ ) during the fissure eruption. Vent distribution of the flank volcanoes of Izu-Oshima Volcano (after Isshiki, 1984) are also shown.

Many geophysical and geological data support this azimuthal change of regional stress. $P$-axes of shallow earthquakes show NNW-SSE to NW-SE trends on the southern side of the Izu-Oshima Island, but show NW-SE to WNW-ESE trends on the western 
side of the island (e.g., Hori, 1989) (Fig. 11(A)). Alignments of flank volcanoes of a composite volcano represent the maximum horizontal compression $\left(\sigma_{H_{\max }}\right)$ azimuth of regional stress (Nakamura, 1977). The submarine flank volcanoes of Izu-Oshima Volcano show vent alignments with NNW-SSE trends on the southeastern side of the Izu-Oshima Island, while they show WNW-ESE alignments on the northwestern side of the island (Hamuro et al., 1980). Both these data suggest that the $\sigma_{H_{\min }}$ azimuths change from ENE-WSW on the southeastern side of the Izu-Oshima Island to NNE-SSW on the northwestern side of the island.

$P$-axes of shallow earthquakes show that the azimuthal change of regional stress occurs in the western part of the Izu-Oshima Island (Fig. 11(A)). This can be seen in many geological and geophysical observations during the 1986 fissure eruption of Izu-Oshima Volcano. The fissure eruption is regarded as a relaxation of the regional stress which had been accumulated by the bending of the PHS plate, and the trends of the fissures and associated geological and geophysical events align with the $\sigma_{H_{\max }}$ of regional stress (e.g., Nakamura, 1988). The distribution of hypocenters (Yamaoka et al., 1988, Fig. 11(B)), and the trends of the cracks and geodetic vertical movements (Endo et al., 1988, Fig. 11(C)), all of which were associated with the fissure eruption, seem to show the directional change from NW-SE in the southeastern and central parts of the island to WNW-ESE in the northwestern part. Hence, all these azimuthal changes can be interpreted as reflections of the azimuthal change of regional stress. In addition, several flank vents in the pre-caldera stage of Izu-Oshima Volcano (3-30 ka) also seem to show a slight azimuthal change of alignment from NW-SE in the eastern and central part of the island to WNW-ESE in the northwestern part (Fig. 11(C)).

As stated above, the WSBF hypothesis explains many geophysical, geomorphological, and geological features in and around the Izu Peninsula and Izu-Oshima Island. Thus, we conclude that the WSBF is most likely to exist in the western Sagami Bay area, and that the plate geometry proposed by the WSBF hypothesis dominates the regional stress field and other tectonic features in and around the Izu Peninsula.

\subsection{Tectonic domains in and around the Izu Peninsula}

In this paper, we propose that the Izu Peninsula is composed of two tectonic domains, the eastern and western Izu blocks (W-Izu and E-Izu in Fig. 10). We also propose three tectonic lines, the Hirayama-Tanaba, Tanaba-Yugashima, and Yugashima-Matsuzaki tectonic lines, which bound the two domains (HTTL, TYTL, and YMTL in Fig. 10).

The three tectonic lines can be recognized as a major fault or fault zone. The Hirayama-Tanaba tectonic line (HTTL) is a fault zone with left-lateral strike-slip displacement. The HTTL is composed of the active Hirayama and Tanna faults (HF and TF in Fig. 10) (e.g., Ito et al., 1987; Matsuda, 1972) and their extensions in the northern and central parts, and of several subpararell faults with NNE-SSW to NE-SW strikes in the southwestern part. The Tanaba-Yugashima tectonic line is recognized as the Mizunuki-Yoichizaka fault (MYF in Fig. 10) and its northwestward extension. The MYF is an active fault with a WNW-ESE strike and right-lateral strike-slip displacement (Hoshino et al., 1978). The Yugashima-Matsuzaki tectonic line is a fault zone with NNE-SSW to NE-SW strikes and left-lateral strike-slip displacement, including the

Vol. 39, No. 1, 1991 
active Kadono fault (KF in Fig. 10) (Hoshino et al., 1978).

The two tectonic domains E-Izu and W-Izu are characterized by the differences in azimuths of regional stress, geologic structure, seismic velocity structure, seismic activity, and paleomagnetic directions. In situ stress measurements, $P$-axes of shallow earthquakes, and trends of Quaternary dikes and faults suggest the systematic azimuthal difference in regional stress between the two blocks (e.g., Tsukahara and Ikeda, 1983, 1987; Hoshino, 1984) (Fig. 10). In the E-Izu block, many active faults have NW-SE to WNW-ESE strikes and right-lateral strike-slip displacement, while active normal faults with N-S strikes are dominant in the W-Izu block (Murai and Kaneko, 1974; Hoshino et al., 1978) (Fig. 10). The Mishima-Shimoda section of seismic refraction studies shows a sharp discontinuity of velocity structures, which is located $2-5 \mathrm{~km}$ below the central part of the Izu Peninsula, near Shuzenji (Asano et al., 1982). The locality of this discontinuity coincides with that of the Hirayama-Tanaba tectonic line (Koyama, 1988), suggesting the difference in the velocity structure between the W-Izu and E-Izu blocks. Seismicity is generally active in the E-Izu in contrast to the low seismicity in the W-Izu (e.g., Earthquake Research Institute, 1982; Okada, 1990). The systematic differences in paleomagnetic directions are stated in the following section. All these results suggest that the upper crusts of the W-Izu and E-Izu blocks are under different tectonic situations at least during the late Quaternary.

Several geodetic and seismic data support the existence of some mechanical boundary between the E-Izu and W-Izu blocks. The eruption of the Teisi Knoll Volcano and associated earthquakes were closely related with the rapid uplifting in the eastern Izu Peninsula since 1975 (e.g., Dambara, 1980; Ishii, 1989; Kuwayama and Fujii, 1990). Through all the phases of this uplifting, the uplifted area seems to be limited within the E-Izu block. The western edge of the uplifted area nearly coincides with the Hirayama-Tanaba tectonic line (HTTL) (Tada and Asano, 1983; Koyama, 1988). The distribution of the aftershocks of the 1978 Izu-Oshima-kinkai earthquake first extended northwestward into the Izu Peninsula, until it attained the vicinity of the Yugashima-Matsuzaki tectonic line (YMTL), and then seems to have moved southwestward along the YMTL (Tsumura et al., 1978).

Besides these tectonic features, volcanoes and their types can be used as a good indicator of tectonic situations (e.g., Nakamura, 1977, 1986). An IGMV, as stated in Sec. 1 , is believed to be an indicator of a tectonic situation with weak constraint on lateral crustal extension, while a composite volcano is generally regarded as an indicator of stronger constraint on the lateral extension. This difference is caused by the stability of a vent system, which supplies magma to the surface (Nakamura, 1986); in an IGMV field, vents can be easily opened at any different places because of weak constraint on lateral crustal extension, resulting in a birth of a new monogenetic volcano, while in a composite volcano field, new vents are prevented from opening because of strong lateral constraint, and the same vent is repeatedly used. On the basis of this idea, the W-Izu and E-Izu blocks can be recognized as volcanotectonic domains.

Most of the vents of the HIMVG are limited within the E-Izu block (Fig. 10). No composite volcanoes are known to have been active in the late Pleistocene and the Holocene in the E-Izu block (Fig. 3). Thus, the E-Izu block can be regarded as a volcanotectonic domain characterized by the activity of an IGMV during the late 
Quaternary.

In the W-Izu block, no volcanism has occurred during the late Pleistocene and Holocene since the cessation of the activity of Daruma and Ida. Volcanoes (Fig. 3), except for the Sanagiyama scoria cone (Shirao, 1981). This small dissected volcano overlies the Daruma Volcano (Figs. 2 and 3), and may be a monogenetic one, considering its small volume of ejecta $\left(0.01 \mathrm{~km}^{3}\right)$. Because of the absence of the data concerning its age and petrographic characteristics, it is unknown whether the Sanagiyama scoria cone is one of the flank volcanoes of Daruma or Ida Volcano, or is a member of the HIMVG. Thus, the volcanotectonic character of the W-Izu block is unclear.

In contrast with the W-Izu and E-Izu blocks, many composite volcanoes, such as Izu-Oshima, Niijima, and Kozushima Volcanoes, are still active in the historical time on the southeastern side of the Izu Peninsula (Figs. 1 and 2). This suggests that the area including these volcanoes belongs to another volcanotectonic domain, the OshimaZenisu block (Fig. 10). As stated above, in this block, the trends of regional stress are probably controlled by the plate bending, which is caused by the subduction of the Izu-Bonin outerarc slab. The location of the boundary between the Oshima-Zenisu and E-Izu volcanotectonic domains should correspond to the boundary between the submarine equivalent of the HIMVG and the submarine flank volcanoes of Izu-Oshima Volcano; the former belongs to an IGMV and the latter constitute a composite volcano.

When the E-Izu volcanotectonic domain was formed ? Several possible monogenetic volcanoes older than the HIMVG exist in the E-Izu block. One of them is Nanzaki Volcano in the southern part of the E-Izu, and the others are the minor effusive bodies of pyroxene dacites (MEBD) (Kuno, 1952) in the northern part of the E-Izu block (Figs. 2,3 , and 10 ).

Nanzaki Volcano is a small volcano located on the southern edge of the Izu Peninsula (Figs. 2 and 10), and is composed of a scoria cone and several lava flows of alkali olivine basalt (Sameshima, 1966; Sumi and Maeda, 1974; Kuroda, 1976). The $\mathrm{K}$-Ar age is $0.43 \pm 0.03 \mathrm{Ma}$ (Kaneoka et al., 1982). The MEBD are five small volcanoes (Izusan, Kamitaga, Higane, Karuizawa, and Kajiya Dacites) distributed in the northern part of the E-Izu block (Figs. 2 and 10), each of which is composed of several lava flows or a lava dome (Kuno, 1952). The fission-track ages of the Kamitaga, Higane, and Kajiya Dacites range from 0.39 to $0.57 \mathrm{Ma}$ (Suzuki, 1970). Kashiwatoge Dacite (Kuno, 1970; Koyama, 1982), located to the south of the MEBD distribution (KST in Fig. 10), may be included in the MEBD, because this volcano is a small dacite dome and occupies a similar stratigraphic horizon to those of the other MEBD volcanoes (Koyama, 1982).

Nanzaki Volcano and the MEBD volcanoes are characterized by small discharge volume and a small number of eruption units, suggesting their monogenetic origin. Thus, the volcanism in the E-Izu block might have had an IGMV character in the middle Pleistocene. However, the activities of the Nanzaki Volcano and MEBD are coeval with those of the other composite volcanoes in the E-Izu block (Fig. 3). The Higane Dacite $(0.57 \mathrm{Ma})$ is stratigraphically intercalated between the Taga and Yugawara Volcanoes (Kuno, 1952). The age of the Kamitaga Dacites (0.51 Ma) is similar to that of the Higane Dacites. This suggests the possibility that the Higane and

Vol. 39, No. 1, 1991 
Kamitaga Dacites do not belong to an IGMV but to the flank volcanoes of Taga Volcano.

In conclusion, typical IGMV activities in the E-Izu block are likely to have started since the initiation of the HIMVG at 140-150 ka. However, the possibility of the existence of an IGMV in the middle Pleistocene cannot completely be denied.

\subsection{Tectonic rotation in the eastern Izu block and its significance}

Paleomagnetism is a useful tool for detecting tectonic movements. Although many paleomagnetic studies aimed to detect the tectonic movements in the Izu Peninsula (Koyama, 1989), few of them treated the Quaternary ones. Kikawa et al. (1989) found the systematic difference of paleomagnetic directions between the W-Izu and E-Izu blocks, and attributed them to differential tilting of each block: westward tilting of the W-Izu and southeastward tilting of the E-Izu block (Fig. 12(B)).

In the W-Izu block, the interpretation by Kikawa et al. (1989) seems to be concordant with the geologic structure showing westward dipping (Kikawa et al., 1989). However, the differential tilting model is inconsistent with the geologic structure of the E-Izu block. Figure 12(A) shows the base-level contour of the Quaternary deposits (Atami Group) in the Izu Peninsula. The base level of the Atami Group is a good indicator of the relative vertical movements in the Izu Peninsula since the early

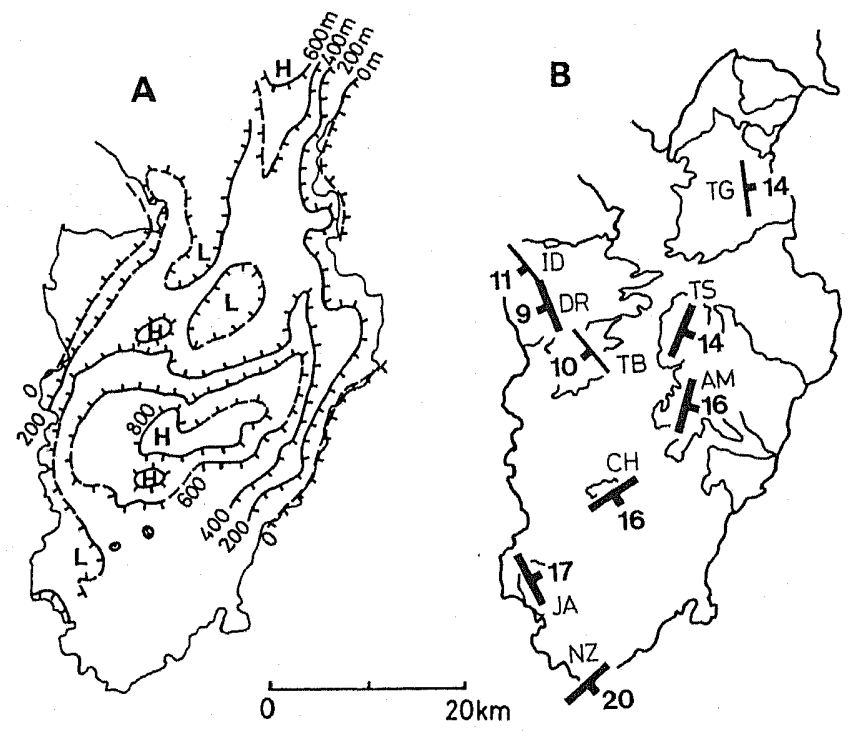

Fig. 12. (A) Present elevation map of the base of the Quaternary deposits in the Izu Peninsula (after Koyama, 1988). $\mathrm{H}$ and L correspond to a topographic high and low, respectively. (B) Tilting direction and angle during the Quaternary, which were calculated from the mean paleomagnetic direction from each volcano on the assumption that the declination anomaly in each volcano was caused by tectonic tilting (after Kikawa et al., 1989). Abbreviations for the volcano names are the same as in Fig. 2. 
Quaternary (Koyama, 1986, 1988). The tilt angle calculated from Fig. 12(A) is at most $10^{\circ}$ in the E-Izu block. This angle and the tilt pattern in the E-Izu block are inconsistent with the tilt angles and directions expected from the differential tilting model (Fig. 12(B)). Thus, tectonic rotation should be required to explain the deflections of paleomagnetic directions.

Figure 13(A) shows a summary of the mean direction of paleomagnetic declination and its confidence limit from each area or volcano (Kikawa et al., 1989; Koyama, 1981; Tsukamoto, 1990; Koyama, unpublished data). Of these data, the site-mean declination directions in the northeastern Izu Peninsula are shown in Fig. 13(B). The systematic difference in paleomagnetic declination between the W-Izu and E-Izu blocks can be seen in both figures. In the E-Izu block, most of the declination directions show counterclockwise deflections, while the declination directions in the W-Izu block show slight clockwise deflections.

Recent paleomagnetic studies revealed that large tectonic rotations in plate boundary regions were caused by block rotations of crustal slivers bounded by subparallel faults (e.g., Ron et al., 1984; Luyendyk et al., 1985; Wells and Heller, 1988) (Fig. 14), and that large detachment faults, which consumes the rotations of slivers, are expected to exist in the upper crust in such regions (e.g., Lemiszki and Brown, 1988). In the northern part of the E-Izu block, many right-lateral strike-slip faults with NNW-SSE to WNW-ESE strikes show subparallel alignments (Figs. 10 and 13), which are similar to those in a sliver rotation model in Fig. 14. Particularly in the area between Ajiro and Ito in Fig. 13(B), both the paleomagnetic directions and the trends of faults seem to have rotated together. This feature is also similar to the rotation model in Fig. 14, which requires the rotation of faults bounding the slivers. The rotation model in Fig. 14 involves the left-lateral strike-slip shearing over the whole block. In the study area, both the HTTL and WSBF, which bound the northern part of the E-Izu block, have left-lateral strike-slip component of displacement, and thus may give shearing over the northern E-Izu block. Thus, we propose the sliver rotation model in Fig. 14 for the tectonic rotations in the northern part of the E-Izu block.

\section{Discussion}

In this section, we try to construct a model of the magma reservoir and eruption of the HIMVG, and to consider why an IGMV exists in the E-Izu block in the late Quaternary, on the basis of the geological, geomorphological, and geophysical features described and discussed in the previous sections.

\subsection{Model of magma reservoir and eruption}

Nakamura $(1977,1986,1989)$ suggests that the formation of a monogenetic volcano is equivalent to the formation of a feeder dike beneath the volcano. Many models for the 1989 Teisi Knoll eruption calculated from geodetic or seismological data suggest that the eruption was associated with the formation of a nearly vertical planar intrusion with an NW-SE strike and 12-13 km depth of its base below the Teisi Knoll Volcano (Tada and Hashimoto, 1989, 1991; Shimazaki, 1989; Okada and Yamamoto, 1989, 1991). This supports Nakamura's idea, and suggests that the eruptions of the other

Vol. 39, No. 1, 1991 

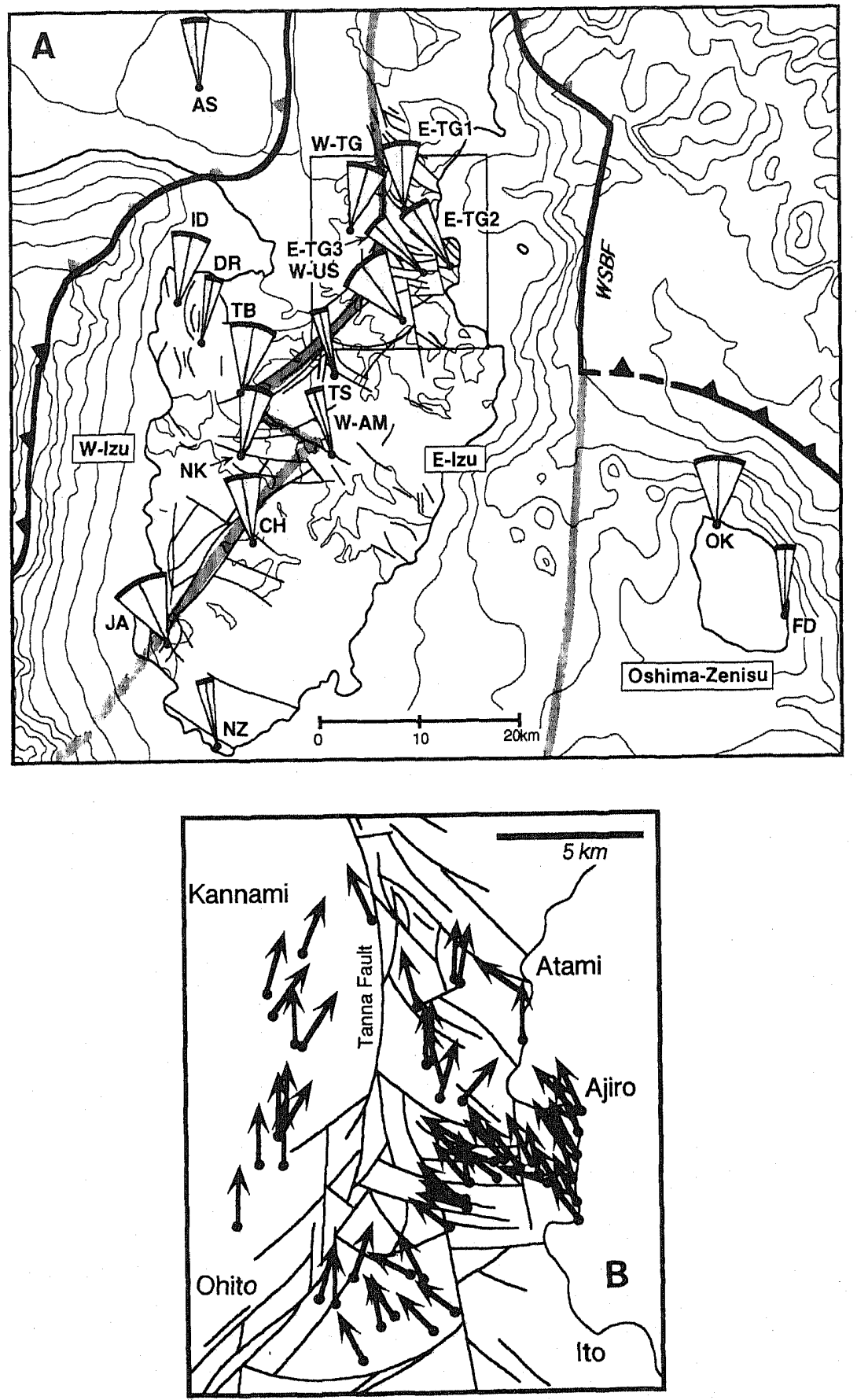

Fig. 13 


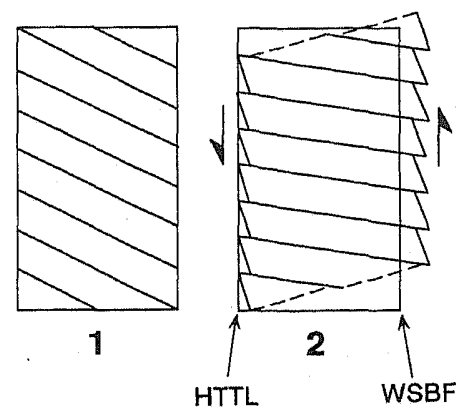

Fig. 14. Schematic diagram showing a mechanism of block rotations of faulted slivers (Garfunkel, 1988). This example shows a model of counterclockwise rotation caused by left-lateral shearing. 1 , initial state; 2 , after rotation. This model can be applied to the northern E-Izu block (see text). In this case, the left and right boundaries of rotated slivers correspond to the Hirayama-Tanaba tectonic line (HTTL) and West Sagami Bay Fracture (WSBF), respectively.

HIMVG volcanoes were equivalent to the formation of dikes.

The eruption models for the Teisi Knoll Volcano stated above also suggest that a magma reservoir, which is the source of the intruded magma, exists near the base of the feeder dike. The volcanic products of the HIMVG include many tonalitic xenoliths or xenocrysts, many of which have been partially melted or corroded (Hamuro, 1985; Miyajima et al., 1985; Miyajima, 1990; Umino et al., 1991). Such a character suggests that a part or the whole of the magma chamber wall touches the tonalitic upper crust. Seismic refraction studies show that the boundary between the upper and lower crusts exists about $15 \mathrm{~km}$ below the Izu Peninsula (Ikami, 1978; Asano et al., 1985). Based on the analysis of reflected seismic waves of microearthquakes, Mizoue et al. (1989) propose the existence of three fluid reservoirs $15 \mathrm{~km}$ below the HIMVG region. Com-

Fig. 13. Map showing the mean directions of paleomagnetic declination. (A) Map showing the mean direction of paleomagnetic declination from each volcano or area. Fan shows the mean direction of declination and its $95 \%$ confidence limit. AS (Ashitaka Volcano), ID (Ida Volcano), DR (Daruma Volcano), TB (Tanaba Volcano), CH (Chokuro Volcano), JA (Jaishi Volcano), NZ (Nanzaki Volcano), TS (Tenshi Volcano), W-AM (western part of Amagi Volcano), OK (Okata Volcano), and FD (Fudeshima Volcano) are after Kikawa et al. (1989). W-US (western part of Usami Volcano) is by Koyama $(1981,1982)$. W-TG (western part of Taga Volcano), and E-TG (eastern part of Taga Volcano) 1-3 are by Tsukamoto (1990). All the directions with reversed polarity were converted to those with normal polarity. The base of each fan is plotted approximately on the center of the sampling sites in each volcano or area. Rectangle shows the range of Fig. 13(B). Other details are the same as those in Fig. 10. (B) Map showing the distribution of major faults (Koyama, 1982; Tsukamoto, 1990; Koyama, unpublished data) and the mean directionof paleomagnetic declination from each site in Taga and Usami Volcanoes. Paleomagnetic data are by Koyama $(1981,1982)$ and Tsukamoto (1990).

Vol. 39, No. 1, 1991 


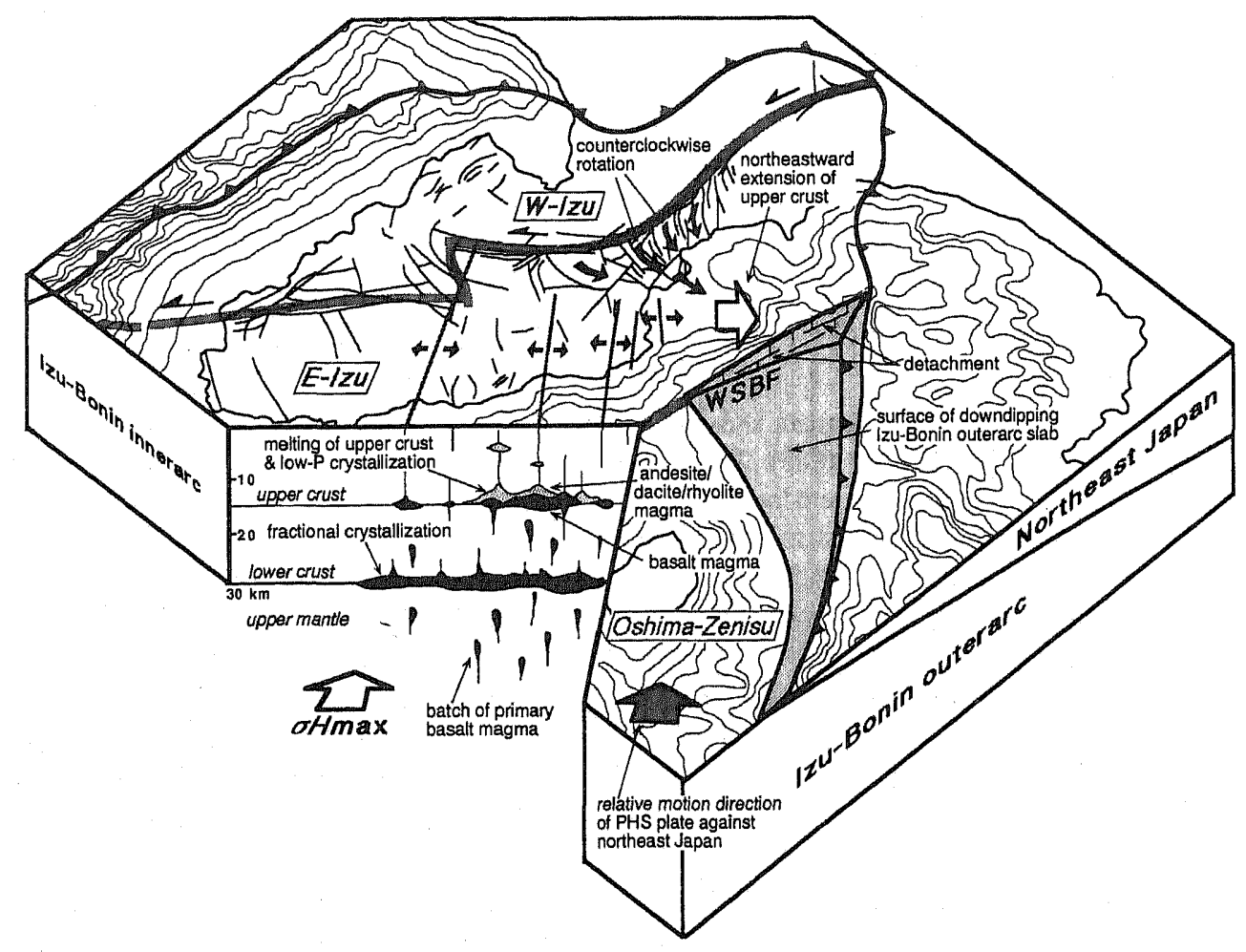

Fig. 15. Schematic diagram showing the model of the tectonovolcanic situation of the late Quaternary Izu Peninsula and adjacent areas. This model systematically explains various tectonic features and why an independent group of monogenetic volcanoes (the Higashi-Izu monogenetic volcano group) exists in the eastern part of the Izu Peninsula. In this figure, Quaternary sediments filling the Sagami basin (shaded area) was removed, and the reader can see the surface of the subducted Izu-Bonin outerarc slab. Other details on the surface are the same as those in Fig. 10. See text for detailed explanation.

bining these results with the models of the Teisi Knoll eruption stated above, the magma chamber(s) of the HIMVG is inferred to be located near the upper/lower crust boundary, of which depth is $12-15 \mathrm{~km}$ (Fig. 15). Ascending magma is probably trapped by the density contrast at this boundary. Similar magma trapping is expected along the Moho, which is another evident density contrast that exists about $30 \mathrm{~km}$ below the Izu Peninsula (Ikami, 1978; Asano et al., 1985). On the basis of petrologic characteristics of the HIMVG products, Umino et al. (1991) estimate another magma chamber(s) around the Moho (Fig. 15).

The total magma discharge volume and rate of the HIMVG have rapidly increased in the latest stage of the eruptive history $(<10 \mathrm{ka})$, and andesitic and dacitic-rhyolitic rocks, which are the products of crustal assimilation, have become dominant in the same period (Fig. 9). Many of the volcanoes with large magma discharge volume 
$\left(>0.04 \mathrm{~km}^{3}\right)$ and with andesitic or dacitic-rhyolitic composition are distributed near the northern central part of the HIMVG distribution (Figs. 4 and 8). Considering the absence of volcanoes with large discharge volume in the early stage of the HIMVG history, Umino et al. (1991) infer that large magma chamber(s) have not existed during the early stage of the eruptive history.

All these observations can be explained by the evolutional history of the HIMVG as stated below. At about $150 \mathrm{Ma}$, ascending batches of basalt magma started to attain the upper crust below the eastern Izu Peninsula. The magma was soon solidified by cooling but gave heat into the crust. Repeated ascending of magma gradually increased the temperature of the crust, and delayed the solidification of magma, resulting in small magma reservoirs in the crust. The existence of the magma reservoirs facilitated the crustal melting and assimilation. The magma reservoirs gradually grew and were connected with each other, forming in a large magma chamber(s) in the latest stage of the eruptive history $(<10 \mathrm{ka}$ ) (Fig. 15). The large magma chamber(s) trapped ascending magma and expanded. In the central part of the distribution of the chamber(s), where the temperature is highest, crustal melting and assimilation proceeded more greatly than in the outer part, and consequently formed the petrologic concentric zoning (Fig. 15).

As stated in the previous section, there is a tendency that the vents of the HIMVG align with the axes of maximum horizontal compressional stress $\left(\sigma_{H_{\max }}\right)$, and that several vents along the same alignment were active during the same period in the eruptive history. The azimuths of these alignments seem to differ systematically from the trends of the adjacent major faults or fault zones (Fig. 10). Some of these vent alignment cross the petrologic zonal structure (Figs. 7 and 8). In Line 3, magma with different chemical composition erupted from different vents in the same period. These observations suggest that the vent opening is mainly controlled by the regional stress field, neither by the existing fractures nor by the pressure in the magma chamber(s).

On the basis of all the facts and considerations stated above, and of the idea for the cause of magma ascent and eruption by Ida (1990), we estimate the scenario of the vent opening of the HIMVG as follows. The vents or intrusives of the HIMVG are formed as open cracks, which are controlled by the regional stress field, and align with the nearly NW-SE $\sigma_{H_{\max }}$ azimuth. The opening of the cracks causes the rapid decrease of magmatic pressure in the magma chamber(s) crossed by the cracks. This pressure decrease triggers the vesiculation of magma which gives the buoyancy for the magma to ascend and fill the cracks. Some of them get enough buoyancy to attain the surface, resulting in an eruption. On the case that the crack is long enough to cross the concentrically zoned magma chamber(s), assimilated magma erupts in the central part of the zonal structure, and more primitive one erupts in the outer parts (Figs. 7 and 15).

\subsection{Why does an IGMV exist in the Izu Peninsula?}

As stated in Sec. 1, in many cases, an IGMV represents a tectonic situation with weak constraint on lateral crustal extension, where a new vent can easily be opened everywhere (Nakamura, 1986). The eruptive history and petrologic characteristics of the HIMVG stated above suggest that the vent opening has been repeated at different places in the distribution area of the HIMVG, and that the vents or intrusives were initially formed as open cracks aligning with the NW-SE trends of maximum horizontal 
compression $\left(\sigma_{H_{\max }}\right)$ of regional stress. This means that the upper crust of the E-Izu block has been extended by the width of a dike at each eruptive or intrusive event, and suggests that the E-Izu block is under weak constraint on lateral extension of the upper crust.

Two contrasting models can explain the cause of the crustal extension. One attributes the NE-SW extension of the E-Izu block to the tensional stress caused by the plate bending (Model 1) (e.g., Nakamura et al., 1984; Tada and Hashimoto, 1990, 1991). The other hypothesizes that the extension of the E-Izu block is caused by the NW-SE compressional stress perpendicular to the extension azimuth, and that the compressional stress is caused by the collision or buoyant subduction of the Izu block with the northeast Japan arc (Model 2) (e.g., Ida, 1991). In this paper, we support Model 2, and discuss its validity.

If the tectonic situation in the E-Izu block is dominated only by tensional stress, the stress field should become a normal fault-type, where the axis of maximum compression $\left(\sigma_{1}\right)$ is nearly vertical. However, the strike-slip-type dominance in active faults and focal mechanisms of shallow earthquakes in the E-Izu block is inconsistent with the normal fault-type stress field. The vertical movement pattern in the Izu Peninsula during the Quaternary shows that the central part of the E-Izu block has undergone oval-shaped uplifting with a nearly ENE-WSW anticlinal axis (Fig. 12(A)). This anticlinal uplifting suggests NNW-SSE shortening of the crust, which is more concordant with Model 2 than Model 1.

The plate geometry involving the West Sagami Bay Fracture (WSBF) is more consistent with Model 2 than Model 1. In this geometry, the northward extension of the Oshima-Zenisu block is subducting beneath the northeast Japan arc, while the northward extension of the E-Izu block is underplating the northeast Japan (Figs. 10 and 15). The absence of a subducting slab, which is directly coupled with the E-Izu block in the Sagami Bay area, is inconsistent with Model 1, because Model 1 requires the plate bending caused by subduction.

NE-SW extension of the E-Izu block is explained by the plate geometry involving the WSBF as follows (Fig. 15). On the eastern side of the WSBF, the Izu-Bonin outerarc subducts beneath the northeast Japan arc, and leaves the buoyant Izu-Bonin innerarc on the western side of the WSBF. The depth contour of the surface of the subducting outerarc shows that the vertical displacement between the inner and outerarcs attains to $>5 \mathrm{~km}$ at the northern edge of the Sagami basin (Figs. 10 and 15). This geometry requires a triangle-shaped $>5 \mathrm{~km}$ depression on the eastern side of the WSBF (Fig. 15). Seismic reflection studies show that the central part of the Sagami basin is filled with Quaternary sediments with $>4 \mathrm{~km}$ thickness (e.g., Kato, 1987; Tokuyama and Soh, 1988), supporting the existence of the buried depression. Along the western edge of this depression, the upper crust of the E-Izu block is directly in contact with the thick younger sediments filling the depression (Fig. 15). In this situation, the upper crust of the E-Izu block is expected to be under weak lateral constraint on northeastward or eastward extension.

As stated in the previous section, counterclockwise rotation of crustal slivers and associated detachments in the upper crust in the northern E-Izu block are inferred from paleomagnetic data (Figs. 13 and 14). Considering the horizontal dimensions of the 
faulted slivers in the northern E-Izu block (1-2 km in sliver width, Fig. 13(B)), the detachments are expected to be located within the upper crust (Fig. 15). If the sliver rotation model in Fig. 14 is the case for the northern E-Izu block, the eduction of the upper crust slivers may occur along the WSBF (Fig. 14), where the upper crust is under weak constraint on lateral extension. Such detachments and sliver eduction may help the northeastward extension of the whole E-Izu upper crust. Thus, both the plate geometry involving the WSBF and the existence of the sliver rotations probably enable the northeastward extension of the upper crust of the E-Izu block, and thus make an IGMV field, where a new planar intrusion is formed in the upper crust at each eruptive or intrusive event.

The WSBF is a propagating fracture resulted from the separation of the Izu-Bonin inner and outerarcs. The southern edge of the WSBF, which is a starting point of fracturing, is expected to have propagated southward, corresponding to the northward motion of the Izu-Bonin arc. The southward propagation of the WSBF probably causes the southward propagation of the zone of crustal extension on the western side of the WSBF. As discussed in the previous section, the E-Izu block has become an IGMV field since the initiation of the HIMVG (140-150 ka) or older (Fig. 3). The activity of the HIMVG started at the northern edge of its distribution and seems to have extended southward (Fig. 7). Another possible IGMV, the MEBD, which has an older age than the HIMVG, is located on the northern side of the HIMVG (Fig. 10). All these observations possibly reflect the southward propagation of the WSBF.

\section{Concluding Remarks}

In this paper, we have summarized the eruptive history, vent distribution, petrologic characteristics, and magma discharge volume and rate of the Higashi-Izu monogenetic volcano group (HIMVG). We have also summarized the tectonic features in and around the Izu Peninsula. Considering all these data, we proposed a model for explaining systematically the present and late Quaternary volcanism and tectonics of the study area, and also discussed why an independent group of monogenetic volcanoes (IGMV) exists in the eastern Izu Peninsula.

As stated in the previous section, Line 5 does not correspond to any vent alignment of the HIMVG (Figs. 8 and 10) or of the Higashi-Izu-oki submarine volcanoes (Figs. 2 and 10). No other historical volcanic activity is known along Line 5, except for the earthquake swarm and rapid crustal uplifting in 1930. Thus, the recent crustal and volcanic activities along Line 5 possibly mean the birth or early stage of a new vent activity of the HIMVG. If the activity along Line 5 continues in the future, another new dike may intrude along this line, or attain the surface, resulting in a new eruption somewhere along this line and its extension.

We appreciate Drs. Yukio Hayakawa, Katsuhiko Ishibashi, Masaki Takahashi, and Eiichi Kikawa for their helpful discussion and suggestions for this study. We greatly acknowledge Drs. $\mathrm{K}$. Ishibashi and Yoshiaki Ida for their critical reviews of the manuscript. We also thank Mr. Kazuyuki Tsukamoto and Miss Megumi Kato for allowing us to use their unpublished data.

Vol. 39, No. 1, 1991 


\section{REFERENCES}

Amano, K., H. Takahashi, T. Tachikawa, K. Yokoyama, C. Yokota, and J. Kikuchi, Geology of Ashigara group-collision tectonics of Izu micro-continent with Eurasian plate, in Essays in Geology: Prof. N. Kitamura Commemorative Volume, ed. H. Nakagawa, T. Kotaka, and Y. Takayanagi, pp. 7-29, Porf. N. Kitamura Taikan Kinenjigyo-kai, Sendai, 1986 (in Japanese with English abstract).

Aramaki, S. and K. Hamuro, Geology of the Higashi-Izu monogenetic volcano group, Bull. Earthq. Res. Inst., Univ. Tokyo, 52, 235-278, 1977 (in Japanese with English abstract).

Asano, S., T. Yoshii, S. Kubota, Y. Sasaki, H. Okada, S. Suzuki, T. Masuda, H. Murakami, N. Nishide, and H. Inatani, Crustal structure in Izu Peninsula, central Japan, as derived from explosion seismic observations 1. Mishima-Shimoda profile, J. Phys. Earth, 30, 367-387, 1982.

Asano, S., K. Wada, T. Yoshii, M. Hayakawa, Y. Misawa, T. Moriya, T. Kanazawa, H. Murakami, F. Suzuki, R. Kubota, and K. Suyehiro, Crustal structure in the northern part of the Philippine Sea plate as derived from seismic observations of Hatoyama-off Izu Peninsula explosions, J. Phys. Earth, 33, 173-189, 1985.

Dambara, T., On the abnormal upheaval of the Earth's crust in the northeastern part of the Izu Peninsula, Geosci. Rep. Shizuoka Univ., 5, 1-15, 1980 (in Japanese with English abstract).

Earthquake Research Institute, Seismic maps of the Kanto district, 1971-1980, Rep. Coord. Comm. Earthq. Predict., 27, 63-73, 1982 (in Japanese).

Endo, H., T. Kamai, and T. Sumii, Invar-wire extensometer observation in Izu-Oshima Volcano, Bull. Volcanol. Soc. Jpn., 33, S179-S188, 1988 (in Japanese with English abstract).

Fujii, T., S. Aramaki, T. Kaneko, Y. Kawanabe, M. Takahashi, Y. Nakayama, J. Hirabayashi, and T. Fukuoka, Ejecta of the 1989 submarine eruption off Izu Peninsula, Abstracts for the Fall Meeting of the Volcanological Society of Japan, 26, 1989 (in Japanese).

Garfunkel, Z., Regional deformation by block translation and rotation, in Paleomagnetic Rotations and Continental Deformation, ed. C. Kissel and C. Laj, pp. 181-208, Kluwer Academic Publishers, Dordrecht, 1988.

Hamuro, K., Geology of Omuroyama volcano group, J. Geol. Soc. Jpn., 84, 433-444, 1978 (in Japanese with English abstract).

Hamuro, K., Petrology of the Higashi-Izu monogenetic volcano group, Bull. Earthq. Res. Inst., Univ. Tokyo, 60, 335-400, 1985.

Hamuro, K., S. Aramaki, H. Kagami, and K. Fujioka, The Higashi-Izu-oki submarine volcanoes. Part 1, Bull. Earthq. Res. Inst., Univ. Tokyo, 55, 259-297, 1980 (in Japanese with English abstract).

Hamuro, K., S. Aramaki, K. Fujioka, T. Ishii, T. Tanaka, and K. Uto, The Higashi-Izu-oki submarine volcanoes, Part 2, and the submarine volcanoes near the Izu Shoto Islands, Bull. Earthq. Res. Inst., Univ. Tokyo, 58, 527-557, 1983 (in Japanese with English abstract).

Hayakawa, Y., Sedimentological studies on volcanic eruptions in the geologic past, Bull. Volcanol. Soc. Jpn., 34, S121-S130, 1990 (in Japanese).

Hayakawa, Y. and M. Yui, Eruption history of the Kusatsu Shirane Volcano, Q. Res., 28, 1-17, 1989 (in Japanese with English abstract).

Heki, K., Paleomagnetic study of the Higashi-Izu monogenetic volcano group and pyroclastic flow deposits in Kagoshima Prefecture: paleosecular variation during the last 40,000 years in Japan, J. Geomag. Geoelectr., 35, 383-390, 1983.

Hori, S., Recent swarm activity around the Izu Peninsula, Rep. NRCDP, 43, 127-167, 1989 (in 
Japanese with English abstract).

Hoshino, K., Neotectonics of Southern Fossa-Magna, a study based on stress measurement and active faults, $Q$. Res., 23, 117-128, 1984 (in Japanese with English abstract).

Hoshino, K., T. Hashimoto, and T. Matsuda, Active faults in Izu Peninsula, Tectonic Map Ser., 4, Geological Survey of Japan, 1978 (in Japanese with English abstract).

Ida, Y., Conditions to start volcanic eruptions, Bull. Volcanol. Soc. Jpn., 35, 299-312, 1990 (in Japanese with English abstract).

Ida, Y., Interpretation of seismic and volcanic activities in the Izu block in relation to collision tectonics, J. Phys. Earth, 39, 421-440, 1991.

Ikami, A., Crustal structure in the Shizuoka district, central Japan, as derived from explosion seismic observations, J. Phys. Earth, 26, 299-331, 1978.

Ishibashi, K., Plate motions in the South Fossa Magna region: application of the Japan Sea subduction hypothesis, Earth Monthly, 6, 61-67, 1984 (in Japanese).

Ishibashi, K., Plate tectonic evolution in the South Fossa Magna, Japan (preliminaries), Earth Monthly, 8, 591-697, 1986 (in Japanese).

Ishibashi, K., 'Kanagawa-ken-seibu Earthquake' and earthquake prediction II, Kagaku, 58, 771-780, 1988 (in Japanese).

Ishii, H., Recent abnormal uplift on the Izu Peninsula (1980-1988), Bull. Earthq. Res. Inst., Univ. Tokyo, 64, 313-324, 1989 (in Japanese with English abstract).

Isshiki, N., Geology of the Kozushima district, Quadrangle Ser., scale 1:50,000, Geological Survey of Japan, 1982 (in Japanese with English abstract).

Isshiki, N., Geology of the Oshima district, Quadrangle Ser., scale 1:50,000, Geological Survey of Japan, 1984 (in Japanese with English abstract).

Isshiki, N., Geology of the Niijima district, Quadrangle Ser., scale 1:50,000, Geological Survey of Japan, 1987 (in Japanese with English abstract).

Ito, T., Y. Uesugi, H. Yonezawa, K. Kano, M. Someno, T. Chiba, and T. Kimura, Analytical method for evaluating superficial fault displacement in volcanic air fall deposits: case of the Hirayama fault, south of Tanzawa mountains, central Japan, since 21,500 years B. P., $J$. Geophys. Res., 92, 10683-10695, 1987.

Kaneoka, I., S. Aramaki, and S. Tonouchi, K-Ar ages of a basanitoid lava flow of Nanzaki Volcano and underlying Miocene andesites from the Irozaki areas, Izu Peninsula, central Japan, J. Geol. Soc. Jpn., 88, 919-922, 1982.

Kaneoka, I., E. Kikawa, and H. Kinoshita, K-Ar ages of volcanic rocks of Daruma and Ida Volcanoes in the Izu Peninsula, central Japan, Bull. Volcanol. Soc. Jpn., 33, 37-41, 1988.

Kasahara, K., Seismic activities of the Kanto district and plate tectonics, Earth Monthly, 7, 105-111, 1984 (in Japanese).

Kato, M., Petrological study of the parental magmas of the Higashi-Izu monogenetic volcano group, Grad. thesis, Inst. Geosci. Shizuoka Univ., 1990 (in Japanese with English abstract).

Kato, S., Multi-channel seismic reflection survey in the Nankai, Suruga, and Sagami troughs, Mar. Geol., 11, 251-268, 1987.

Kato, S., M. Tsuchide, and Observation Team of the Hydrographic Department, 1989 submarine eruption and topographic change of the Teishi Knoll off eastern Izu Peninsula, J. Geogr., 99, 10-19, 1990 (in Japanese).

Kikawa, E., M. Koyama, and H. Kinoshita, Paleomagnetism of Quaternary volcanics in the Izu Peninsula and adjacent areas, Japan, and its tectonic significance, J. Geomag. Geoelectr., 41, 175-201, 1989.

Vol. 39, No. 1, 1991 
Kitazato, H., Paleogeography in the South Fossa Magna, Japan, Earth Monthly, 8, 605-611, 1986 (in Japanese).

Kobayashi, Y., On the existence of 'tectonic stress province,' Earth Monthly, 8, 569-572, 1980 (in Japanese).

Kobayashi, Y., On the initiation of subduction of plates, Earth Monthly, 5, 510-514, 1983 (in Japanese).

Kono, Y. and N. Furuse, 1:1 Million Scale Gravity Anomaly Map in and around the Japanese Islands, The University of Tokyo Press, Tokyo, 1989 (in Japanese with English abstract).

Koyama, M., Paleomagnetism of the Cenozoic deposits in the northeastern part of the Izu Peninsula, central Japan, Rock Mag. Paleogeophys., 8, 1-8, 1981.

Koyama, M., Stratigraphy of the upper Cenozoic strata in the northeastern part of the Izu Peninsula, central Japan, Geosci. Rep. Shizuoka Univ., 7, 61-85, 1982 (in Japanese with English abstract).

Koyama, M., Geologic history of the Izu Peninsula and Quaternary deformations of the Ashigara and Oiso areas, Earth Monthly, 8, 743-752, 1986 (in Japanese).

Koyama, M., The past and present of the Izu Peninsula, in Site Proposals for the Japanese Continental Scientific Drilling I, ed. N. Niitsuma and S. Aramaki, pp. 1-32, Working Group on the Japanese Continental Scientific Drilling, Shizuoka, 1988 (in Japanese).

Koyama, M., Paleomagnetic studies in the South Fossa Magna and adjacent areas, Japan, Mod. Geol., 14, 69-86, 1989.

Koyama, M., and Y. Hayakawa, Eruptive history of the Higashi-Izu monogenetic volcano field by tephrochronology and loesschronometry, Abstracts for the Fall Meeting of the Volcanological Society of Japan, 1990 (in Japanese).

Kuno, H., Geologic Map 'Atami,' Scale 1:75,000 and Explanetary Text, Geological Survey of Japan, 1952 (in Japanese with English abstract).

Kuno, H., Geology and petrology of Omuroyama Volcano Group, North Izu, J. Fac. Sci., Univ. Tokyo, Sec. 2, 9, 241-265, 1954.

Kuno, H., Geologic Map 'Ito,' Scale 1:50,000, Geological Survey of Japan, 1970.

Kuroda, N., Basanitic lava of Nanzaki Volcano, south Izu, central Japan, Mem. Geol. Soc. Jpn., 13, 381-387, 1976 (in Japanese with English abstract).

Kuwayama, T. and Y. Fujii, Change of mode of crustal deformation in the Izu Peninsula, Honshu, Japan and bending of the northernmost part of the Philippine Sea plate, Zisin, 43, 101-110, 1990 (in Japanese with English abstract).

Lemiszki, P. J. and L. D. Brown, Variable crustal structure of strike-slip fault zones as observed of deep seismic reflection profiles, Geol. Soc. Am. Bull., 100, 665-676, 1988.

Luyendyk, B. P., M. J. Kamerling, R. R. Terres, and J. S. Hornafius, Simple shear of southern California during Neogene time suggested by paleomagnetic declinations, J. Geophys. Res., 90, 12454-12466, 1985.

Matsuda, T., Surface faults associated with Kita-Izu Earthquake of 1930, in The Izu Peninsula, ed. M. Hoshino and H. Aoki, pp. 73-94, Tokai University Press, Tokyo, 1972 (in Japanese with English abstract).

Minster, J. B. and T. H. Jordan, Present-day plate motion, J. Geophys. Res., 83, 5331-5354, 1978.

Minster, J. B. and T. H. Jordan, Rotation vectors for the Philippine and Rivera plates, EOS, 60, 958, 1979.

Miyajima, H., Petrology of Higashi-Izu monogenetic volcano group-implication of xenocrysts, time and spacial variation of ejecta, J. Mineral. Petrol. Econ. Geol., 85, 315-336, 1990 (in 
Japanese with English abstract).

Miyajima, H., T. Yoshida, and K. Aoki, Geochemical study of the Higashi-Izu monogenetic volcano group, Rep. Nuclear Res. Inst., 18, 158-174, 1985 (in Japanese with English abstract).

Mizoue, M., I. Nakamura, I. Ogino, and T. Jidaka, Detection of $\mathrm{S} \times \mathrm{P}$ and $\mathrm{S} \times \mathrm{S}$ waves resulted from the reflection in the deep crust in the eastern Izu Peninsula, Japan, Abstracts for the Fall Meeting of the Seismological Society of Japan, 210, 1989 (in Japanese).

Mizuno, K., K. Okumura, Y. Sugiyama, and H. Yamazaki, Estimated age of the older volcanism of Higasi-Izu region based on some widespread tephras, Abstracts for the 20th Meeting of the Japan Association for Quaternary Research, 124-125, 1990 (in Japanese).

Murai, I. and S. Kaneko, The Izu-Hanto-oki earthquake of 1974 and the earthquake faults, especially the relationships between the earthquake faults, the active faults, and the fracture systems in the earthquake area, Earthq. Res. Inst. Prompt Rep., 14, 159-203, 1974 (in Japanese with English abstract).

Nakamura, K., Volcanoes as possible indicators of tectonic stress orientation-principle and proposal, J. Volcanol. Geotherm. Res., 2, 1-16, 1977.

Nakamura, K., Possible nascent trench along the eastern Japan Sea as the convergent boundary between Eurasian and North American plates, Bull. Earthq. Res. Inst., Univ. Tokyo, 58, 711-722, 1983 (in Japanese with English abstract).

Nakamura, K., Volcanology and the plate tectonics, Bull. Volcanol. Soc. Jpn., 30, S1-S16, 1986 (in Japanese with English abstract).

Nakamura, K., Volcanoes as mechanically weak spots in the crust, with special reference to the 1986 eruption of Izu-Oshima Volcano, Bull. Volcanol. Soc. Jpn., 33, S1-S6, 1988 (in Japanese with English abstract).

Nakamura, K., Volcanoes and the Plate Tectonics, The University of Tokyo Press, Tokyo, 1989 (in Japanese).

Nakamura, K., K. Shimazaki, and N. Yonekura, Subduction, bending, and eduction. Present and Quaternary tectonics of the northern border of the Philippine Sea plate, Bull. Soc. Geol. Fr., 26, 221-243, 1984.

Nakano, Y., O. Sugita, H. Inokuchi, and Y. Kobayashi, Tectonics of the Izu Peninsula based on dikes, Earth Monthly, 2, 103-109, 1980 (in Japanese).

Okada, Y., Seismotectonics in the southern Kanto district, central Japan, Zisin, 43, 153-175, 1990 (in Japanese with English abstract).

Okada, Y. and E. Yamamoto, An interpretation of the 1989 off Ito earthquake swarm and volcanic activity, Abstracts for the Fall Meeting of the Seismological Society of Japan, 118, 1989 (in Japanese).

Okada, Y. and E. Yamamoto, A model for the 1989 seismo-volcanic activity off Ito, central Japan, derived from crustal movement data, J. Phys. Earth, 39, 177-195, 1991.

Oshima, S., M. Tsuchide, S. Kato, S. Okubo, K. Watanabe, K. Kudo, and J. Ossaka, Birth of a submarine volcano "Teisi Knoll," J. Phys. Earth, 39, 1-19, 1991.

Ron, H., R. Freund, Z. Garfunkel, and A. Nur, Block rotation by strike-slip faulting: structural and paleomagnetic evidence, J. Geophys. Res., 89, 6256-6270, 1984.

Sameshima, T., Guidebook for the geology of the Izu Peninsula, Publ. Geol. Assoc. Shizuoka Pref., No. 9, 1-17, 1966 (in Japanese).

Seno, T., "Northern Honshu microplate" hypothesis and tectonics in the surrounding region, $J$. Geod. Soc. Jpn., 31, 106-123, 1985 (in Japanese with English abstract). 
Shimazaki, K., Tectonics of dike intrusions off the eastern Izu Peninsula, in Volcanoes and the Plate Tectonics, pp. 252-256, The University of Tokyo Press, Tokyo, 1989 (in Japanese).

Shirao, M., Geology of Daruma Volcano and adjacent areas, Izu Peninsula, Japan, J. Geol. Soc. $J p n ., 87,641-655,1981$ (in Japanese with English abstract).

Somerville, P., The accommodation of plate collision by deformation in the Izu block, Japan, Bull. Earthq. Res. Inst., Univ. Tokyo, 53, 629-648, 1978.

Soya, T., K. Uto, T. Yamamoto, S. Sudo, S. Togashi, S. Nakano, K. Sakaguchi, K. Kikkawa, K. Mizuno, A. Takada, and K. Ono, Submarine eruption and products of the July1989 off the eastern Izu Peninsula, Chishitsu News, 422, 14-26, 1989 (in Japanese).

Sugihara, S., Marine terraces and fault topography of Hatsushima Island, Atami, Japan, Bull. Inst. Human Sci., Univ. Meiji, 19, 1-25, 1981 (in Japanese).

Sumi, K. and K. Maeda, Finding of alkali olivine basalt from the southern part of Izu Peninsula, J. Geol. Soc. Jpn., 80, 137-140, 1974 (in Japanese).

Suzuki, M., Fission track dating and uranium contents of obsidian (II), Q. Res., 9, 1-6, 1970 (in Japanese with English abstract).

Tada, T. and S. Asano, Anomalous crustal uplift and crustal structure in the Matsushiro and the Izu Peninsula earthquake swarm regions, Tectonophysics, 97, 241-250, 1983.

Tada, T. and M. Hashimoto, On the cause of the abnormal crustal movements in the northeastern Izu Peninsula (3) open crack model and the activity of the 1988 summer, Abstracts for the Spring Meeting of the Seismological Society of Japan, 41, 1989 (in Japanese).

Tada, T. and M. Hashimoto, Fissure events in the northwestern part of the Sagami Bay and its tectonic significance, Abstracts for the 1990 Joint meeting of the Japanese Societies of Earth and Planetary Sciences, 91, 1990 (in Japanese).

Tada, T. and M. Hashimoto, Anomalous crustal deformation in the northeastern Izu Peninsula and its tectonic significance-tension crack model-, J. Phys. Earth, 39, 197-218, 1991.

Tokuyama, H. and W. Soh, When was the Sagami trough formed ?, Earth Monthly, 10, 630-637, 1988 (in Japanese).

Tsukahara, H. and R. Ikeda, State of stress in the Kanto-Tokai area, Zisin, 36, 571-586, 1983 (in Japanese with English abstract).

Tsukahara, H. and R. Ikeda, Hydraulic fracturing stress measurements and in-situ stress field in the Kanto-Tokai area, Japan, Tectonophysics, 135, 329--345, 1987.

Tsukamoto, K., Geological structure and paleomagnetism of Taga Volcano and its basement in the northeastern Izu Peninsula, central Japan, Grad. thesis, Inst. Geosci. Shizuoka Univ., 1990 (in Japanese with English abstract).

Tsumura, K., I. Karakama, I. Ogino, and M. Takahashi, Seismic activities before and after the Izu-Oshima-kinkai earthquake of 1978, Bull. Earthq. Res. Inst., Univ. Tokyo, 53, 675-706, 1978 (in Japanese with English abstract).

Ukawa, M., Collision and fan-shaped compressional stress pattern in the Izu block at the northern edge of the Philippine Sea plate, J. Geophys. Res., 96, 713-728, 1991.

Umino, S., M. Kato, and M. Koyama, Diversity of parent magmas of Higashi-Izu monogenetic volcano group, J. Phys. Earth, 39, 371-389, 1991.

Wells, R. E. and P. L. Heller, The relative contribution of accretion, shear, and extension to Cenozoic tectonic rotation in the Pacific Northwest, Geol. Soc. Am. Bull., 100, 325-338, 1988.

Yamaoka, K., H. Watanabe, and S. Sakashita, Seismicity during the 1986 eruption of Izu-Oshima Volcano, Bull. Volcanol. Soc. Jpn., 33, S91-S101, 1988 (in Japanese with English abstract). 